\title{
Modulatory Effect of Polyphenolic Compounds from the Mangrove Tree Rhizophora mangle L. on Non-Alcoholic Fatty Liver Disease and Insulin Resistance in High-Fat Diet Obese Mice
}

\author{
Leonardo Mendes de Souza Mesquita ${ }^{1}$, Cíntia Rabelo e Paiva Caria 2 (1D, Paola Souza Santos ${ }^{2}$, \\ Caio Cesar Ruy ${ }^{2}$, Natalia da Silva Lima ${ }^{2}$, Débora Kono Taketa Moreira ${ }^{2}$, \\ Claudia Quintino da Rocha ${ }^{1,3}$ (1D), Daniella Carisa Murador ${ }^{4}$, Veridiana Vera de Rosso ${ }^{4}$, \\ Alessandra Gambero ${ }^{2}$ and Wagner Vilegas ${ }^{1, *}$ (iD \\ 1 UNESP—São Paulo State University/Coastal Campus of São Vicente, Laboratory of Bioprospection of \\ Natural Products (LBPN) Pça Infante Dom Henrique S/N, 11330-900 São Vicente, SP, Brazil; \\ mesquitalms@gmail.com (L.M.d.S.M.); claudiarocha3@yahoo.com.br (C.Q.d.R.) \\ 2 Clinical Pharmacology and Gastroenterology Unit, USF-São Francisco University, Av. São Francisco \\ de Assis, 218, 12916-900 Bragança Paulista, SP, Brazil; cintiarabello@yahoo.com.br (C.R.e.P.C.); \\ pa.s.santos@hotmail.com (P.S.S.); ruyccaio@gmail.com (C.C.R.); lima.nat@gmail.com (N.d.S.L.); \\ deboraktmoreira@gmail.com (D.K.T.M.); alessandra.gambero@usf.edu.br (A.G.) \\ 3 Laboratório de Estudos Avançados em Fitomedicamentos (LEAF), UFMA-Federal University of Maranhão, \\ Av. dos Portugueses, 1966-Bacanga, CEP: 65080-805 São Luís, Maranhão, Brazil \\ 4 Department of Biosciences, Federal University of São Paulo (UNIFESP), Silva Jardim Street, 136, \\ Vila Mathias, 11015-020 Santos City, SP, Brazil; daniellamurador@gmail.com (D.C.M.); \\ veriderosso@yahoo.com (V.V.d.R.) \\ * Correspondence: vilegasw@gmail.com; Tel.: +55-13-996-195-031
}

Received: 12 July 2018; Accepted: 11 August 2018; Published: 22 August 2018

\begin{abstract}
No scientific report proves the action of the phytochemicals from the mangrove tree Rhizophora mangle in the treatment of diabetes. The aim of this work is to evaluate the effects of the acetonic extract of $R$. mangle barks (AERM) on type 2 diabetes. The main chemical constituents of the extract were analyzed by high-performance liquid chromatography (HPLC) and flow injection analysis electrospray-iontrap mass spectrometry (FIA-ESI-IT-MS/MS). High-fat diet (HFD)-fed mice were used as model of type 2 diabetes associated with obesity. After 4 weeks of AERM 5 or $50 \mathrm{mg} / \mathrm{kg} /$ day orally, glucose homeostasis was evaluated by insulin tolerance test (kiTT). Hepatic steatosis, triglycerides and gene expression were also evaluated. AERM consists of catechin, quercetin and chlorogenic acids derivatives. These metabolites have nutritional importance, obese mice treated with AERM $(50 \mathrm{mg} / \mathrm{kg})$ presented improvements in insulin resistance resulting in hepatic steatosis reductions associated with a strong inhibition of hepatic mRNA levels of CD36. The beneficial effects of AERM in an obesity model could be associated with its inhibitory $\alpha$-amylase activity detected in vitro. Rhizophora mangle partially reverses insulin resistance and hepatic steatosis associated with obesity, supporting previous claims in traditional knowledge.
\end{abstract}

Keywords: polyphenols; type 2 diabetes; non-alcoholic fatty liver disease; CD36; catechins

\section{Introduction}

On the Brazilian coast, mangrove is one of the most representative biomes. This ecosystem is characterized as a transitional environment between terrestrial and aquatic ecosystems, and it is continuously threatened by real estate speculation and harbor construction [1]. Mangrove plants are 
potential sources of biologically active compounds and have wide application in ethnopharmacological practices. The habitat of these species is under stressful environmental conditions (salinity, temperature, tidal fluctuations, and anoxic soil). These plants are morphologically and physiologically adapted to this inhospitable environment. Therefore, they might present many substances which protect them from these adverse environmental [2].

Several medicinal plants are used as complementary therapy for diabetes, and studies demonstrating their efficacy and safety are still being developed [3]. Many reports document the increasing use of medicinal plants by modern populations in Mexico and Latin America [4]. No scientific report proves the action of the phytochemicals from the mangrove tree Rhizophora mangle in the treatment of diabetes. In this context, according to Andrade-Cetto and Heinrich, (2005), the barks of $R$. mangle L. (Rhizophoraceae) have been widely reported in traditional Mexican medicine to have antidiabetic property. Furthermore, R. mangle is commonly used in Latin America to treat inflammation, angina, asthma, pain, diarrhea, ulcers, tumors, and seizures $[2,5,6]$.

Type 2 diabetes mellitus (T2D) is a major public health problem worldwide and the prevalence has been steadily increasing over the past few decades [7]. About $60 \%$ of Brazilian population is overweight or obese, and associated diseases such as T2D and non-alcoholic fatty liver disease (NAFLD) are becoming increasingly prevalent in the Brazilian population [8]. Diabetes is usually treated and managed using pharmacological drugs, which produce side effects, such as weight gain, edema, hypoglycemia, lactic acidosis, liver toxicity, and gastrointestinal disturbances after long-term use [9]. A recommended alternative for the treatment of diabetes is the use of traditional medicinal plants [10].

Rhizophora mangle L. (Rhizophoraceae) is one of the most prominent species in Brazilian mangrove ecosystems, which is a largely unexplored source of biological compounds with huge medicinal potential [11]. Phenolic compounds are the main source of phytochemicals found in mangrove plants, especially condensed tannins [12]; their barks are comprised of proanthocyanidins (PAs), oligomers, and polymers by flavan-3-ol, which have high antioxidant and anti-inflammatory activity [13]. PAs are widely distributed throughout the plant kingdom and are the second-most frequent phenolic substances, after lignins [14]. Polyphenols of plant origin can also help to prevent obesity and adipose tissue inflammation and improve obesity-associated metabolic syndrome in human subjects and animal models of obesity [15]. Our research group has previously obtained positive results with $R$. mangle acetone extract (AERM) for the treatment and prevention of gastrointestinal diseases [12,16]. However, a more detailed chemical analysis of AERM is needed to characterize the main chemical constituents.

Therefore, in this study, we characterized the chemical composition of the standardized AERM and investigated the effect of AERM on glucose homeostasis, adipose tissue inflammation, and hepatic steatosis in an experimental model of diet-induced obesity in mice. In addition, the potential antioxidant, anti-amylase, and anti-lipase of the extract was evaluated in vitro.

\section{Results and Discussion}

\subsection{Chemical Characterization of Extracts}

To obtain the most useful chemical information and optimal separation in the fingerprint chromatograms of AERM, the mobile phase compositions, gradient elution procedure, and detection wavelength were optimized. With the aim of enhancing resolution, glacial formic acid (FA) was added to the binary mixture of methanol-water. To acquire better selectivity and higher efficiency, different concentrations of FA $(0.05 \%, 0.1 \%$ and $0.5 \%)$ in the aqueous phase were also investigated. The mobile phase consisting of a water- $0.1 \%$ FA solution was chosen for the determination of AERM with many peaks on the chromatogram within $70 \mathrm{~min}$. The wavelength was also optimized to obtain the highest number of compounds detected.

Baseline resolution was optimized using the HPLC-PDA method. We observed seven main peaks in AERM, with maximum absorbance values around 232 and $278 \mathrm{~nm}$, which covered more than $90 \%$ 
of the total chromatogram area (Figure 1A). Based on the UV spectrum of each chromatographic peaks (1-7) (Figure 1B), the constituents of AERM could be classified as catechin derivatives $\left(\lambda_{\max } 280 \mathrm{~nm}\right)$, which can polymerize, forming condensed tannins known PA [17]. The presence of condensed tannins in this extract was also confirmed by the presence of a low chromatographic resolution peak eluting between $R_{t}$ 55-70 min. In spite of tannins are common in plants that occur in mangrove ecosystems [18], this work is the first to characterize and propose a fragmentation pathway of the condensed tannins in the acetonic extract from R. mangle barks. Oo et al. (2008) [19] and Zhang et al. (2010) [20] described the occurrence of catechins, epicatechins, and epigalocatechins in R. apiculata and R. mangle.

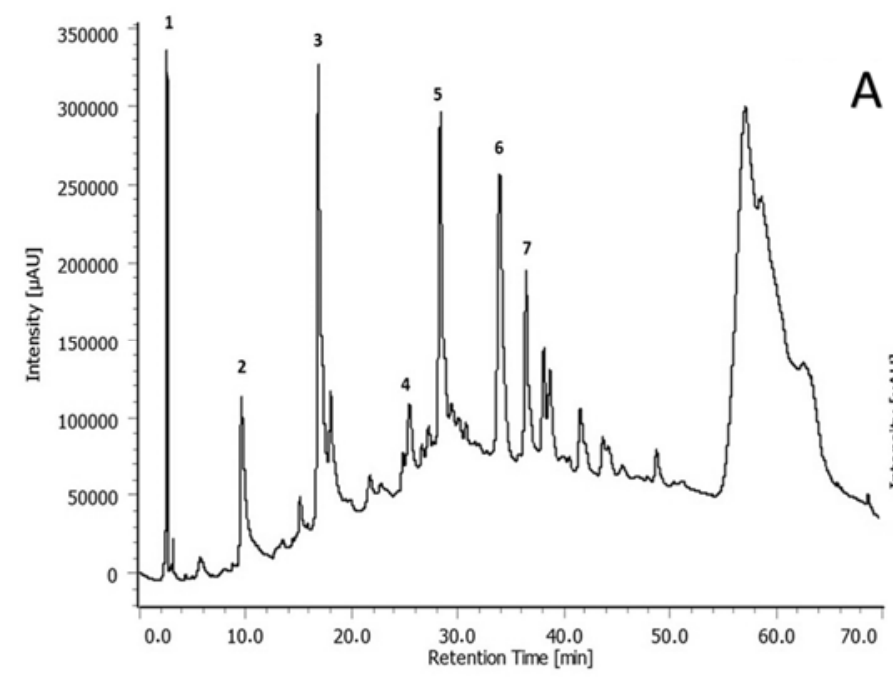

A

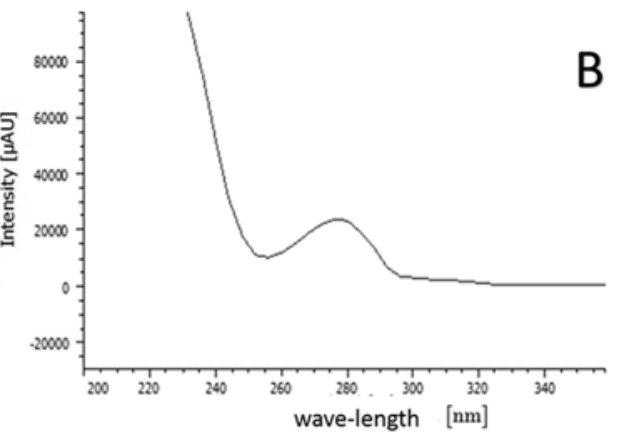

Figure 1. Compounds detected in the AERM $(210 \mathrm{~nm})$. Analytical HPLC-PDA chromatogram (A) and the corresponding UV spectra (peaks 1-7) (B).

However, HPLC-PDA analyses were not sufficient to fully characterize the condensed tannins in AERM. According to Li et al. (2007) [21], ESI-MS techniques have been used efficiently for the characterization of several natural compounds, mainly polyphenolic compounds. Furthermore, MS/MS fragmentation of the flow injection analysis electrospray-ion trap mass spectrometry (FIA-ESI-IT-MS/MS) can generate product ions that give additional information about the structure of these compounds. FIA-ESI-IT-MS/MS has previously been applied to establish the polyphenol profile of complex matrices [22]. Thus, we decided to use this technique to obtain a qualitative metabolic fingerprint of the AERM, following clean-up using solid-phase extraction (SPE).

To obtain qualitative information on PA in AERM, a sample rich in these compounds was prepared and directly injected into the ESI source of the mass spectrometer. We tested both positive and negative ionization, and the best results were obtained with negative mode. It has previously been reported that negative ionization is more sensitive and selective than positive ionization [23]. Figure 2 and Table 1 show the ESI-MS fingerprint obtained using full scan, showing the $[\mathrm{M}-\mathrm{H}]^{-}$ions of the compounds present in the extract. After MS/MS experiments with each peak observed in the full-scan spectrum, three main mechanisms of fragmentation were observed: retro-diels-alder (RDA), quinone methide $(\mathrm{QM})$, and heterocyclic ring fission (HRF) [24]. The fragmentation patterns revealed the presence of three series of polymeric PAs. In the full-scan experiment, the $m / z 289$ ion represented one unit of catechin. In addition, we observed a first series of ions separated by $288 \mathrm{Da}$ corresponding to ion peaks of dimeric $(m / z 577)$ and trimeric $(m / z$ 865) PA. We detected a second series of PAs, based on a catechin core linked to hexose moieties ( $m / z$ 451: monomer; $m / z$ 739: dimer). A third series of PAs is represented by catechins linked to deoxyhexose moieties $(m / z$ 435: monomer; $m / z$ 723: dimer). 


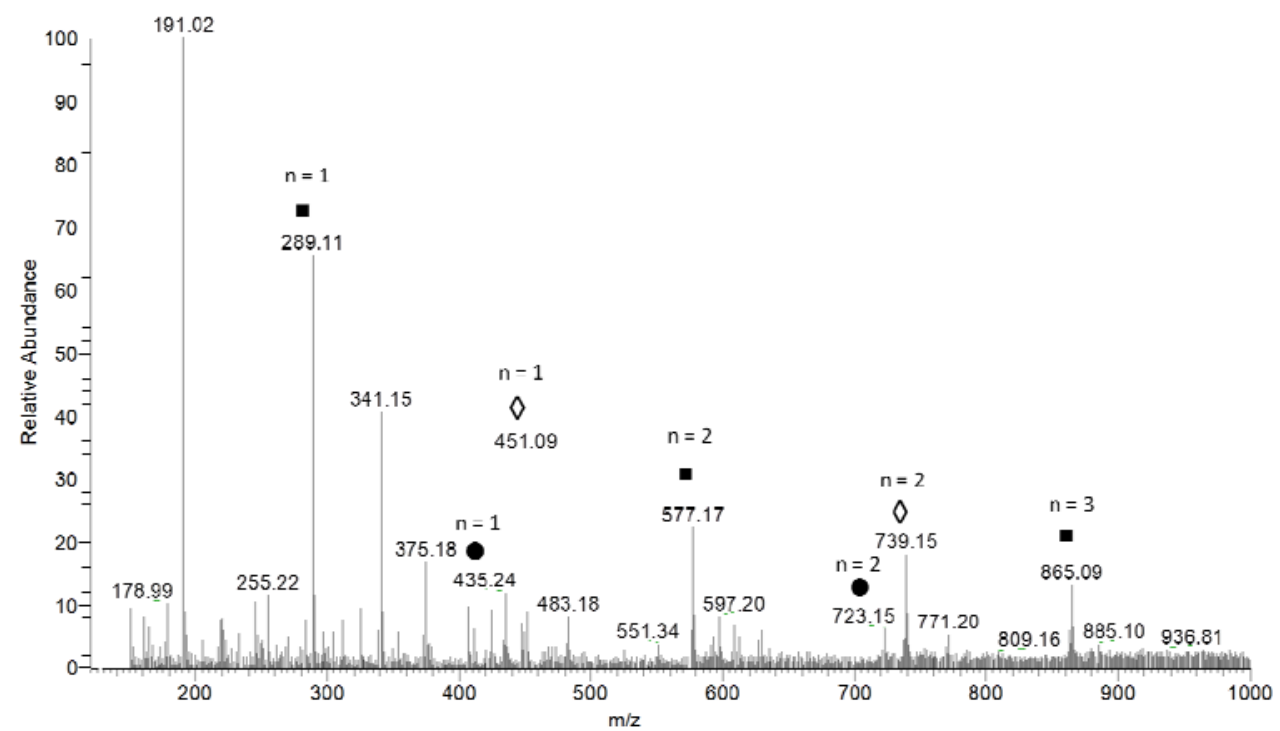

Figure 2. First-order mass spectrum of AERM evaluated by negative mode ionization. $n=$ number of catechins units; $\mathbf{\square}$ catechin derivatives; $\bullet$ deoxyhex-catechin derivatives; $\diamond$ hexose-catechin derivatives.

Table 1. $m / z[\mathrm{M}-\mathrm{H}]^{-}$ion, $\mathrm{MS}^{\mathrm{n}}$ fragments of the compounds obtained by FIA-ESI-IT-MS/MS of the AERM.

\begin{tabular}{|c|c|c|c|}
\hline$m / z[\mathrm{M}-\mathrm{H}]^{-}$ & MS $^{2}$ & MS $^{3}$ & Proposed Name \\
\hline 289 & $137[\mathrm{M}-152-\mathrm{H}]^{-}$ & & catechin \\
\hline 435 & $283\left[^{\mathrm{M}-152-\mathrm{H}]^{-}}\right.$ & 137 [M-152-146-H] $^{-}$ & catechin + deoxyhexose \\
\hline 451 & 299 [M-152-H] $^{-}$ & 137 [M-152-162-H] $^{-}$ & catechin + hexose \\
\hline 515 & $353[\mathrm{M}-162-\mathrm{H}]^{-}$ & $191[\mathrm{M}-162-162-\mathrm{H}]^{-}$ & dicaffeoyl-quinic acid \\
\hline 577 & $\begin{array}{l}451[\mathrm{M}-126-\mathrm{H}]^{-} \\
425[\mathrm{M}-152-\mathrm{H}]^{-} \\
289[\mathrm{M}-288-\mathrm{H}]^{-}\end{array}$ & & catechin dimer \\
\hline 609 & $\begin{array}{l}463 \text { [M-146-H] }^{-} \\
301 \text { [M-308-H] }^{-}\end{array}$ & & rutin \\
\hline 723 & 571 [M-152-H] $^{-}$ & $419[\mathrm{M}-152-\mathrm{H}]^{-}$ & catechin dimer + deoxyhexose \\
\hline 739 & $587\left[^{\mathrm{M}-152-\mathrm{H}]^{-}}\right.$ & $\begin{array}{c}569\left[^{[\mathrm{M}-18-\mathrm{H}]^{-}}\right. \\
435\left[^{-}-152-\mathrm{H}\right]^{-}\end{array}$ & catechin dimer + hexose \\
\hline 865 & $577[\mathrm{M}-288-\mathrm{H}]^{-}$ & $\begin{array}{l}451[\mathrm{M}-126-\mathrm{H}]^{-} \\
425[\mathrm{M}-152-\mathrm{H}]^{-} \\
289[\mathrm{M}-288-\mathrm{H}]^{-}\end{array}$ & catechin trimer \\
\hline 1153 & $865[\mathrm{M}-288-\mathrm{H}]^{-}$ & $\begin{array}{c}847[\mathrm{M}-18-\mathrm{H}]^{-} \\
739[\mathrm{M}-126-\mathrm{H}]^{-} \\
587[\mathrm{M}-278-\mathrm{H}]^{-} \\
577[\mathrm{M}-288-\mathrm{H}]^{-} \\
451[\mathrm{M}-414-\mathrm{H}]^{-}\end{array}$ & catechin tetramer \\
\hline
\end{tabular}

The MS ${ }^{2}$ spectrum of the ion at $m / z 577$ (Figure 3) showed major fragments at $m / z 451,425$, and 289. The ion at $m / z 451$ arises from the loss of 126 mass units, corresponding to the HRF fragmentation. The ion at $m / z 425$ was derived from the loss of $152 \mathrm{Da}$ from the precursor ion at $m / z$ 577 and was proposed to arise from an RDA fragmentation. The fragment at $m / z 289[\mathrm{M}-288-\mathrm{H}]^{-}$ was assigned to a QM fragmentation of the catechin dimer. These fragmentation patterns have been previously described and confirm the presence of PAs [25]. 


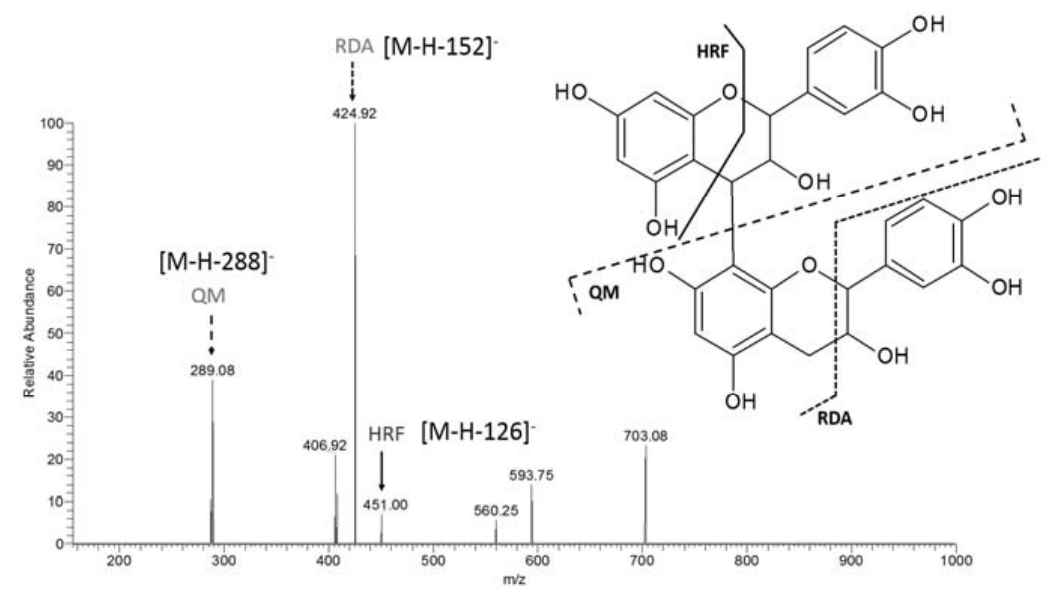

Figure 3. MS/MS spectrum of the ion at $m / z 577$ evidencing the main patterns of fragmentation of PAs. $\mathrm{HRF}=$ heterocyclic ring fission; $\mathrm{RDA}=$ Retro Dies-Alder fragmentation; $\mathrm{QM}$ = quinone-methide fragmentation.

The PA series containing hexose-catechins was also investigated using the same approach. The MS ${ }^{2}$ spectrum of the ion at $m / z 739$ generated the product ion at $m / z 587[\mathrm{M}-152-\mathrm{H}]^{-}$, due to RDA fragmentation (Figure 4A), followed by another RDA [M-152-152-H] $]^{-}$fragmentation, generating the ion at $m / z 435$ (Figure 4B). This fragmentation pattern allowed us to presume the position of the sugar moiety either at ring A or D (Figure 4A,B). Similar fragmentation patterns occurred with the third PA series containing a deoxyhexose moiety $(m / z 435$ and 723$)$.

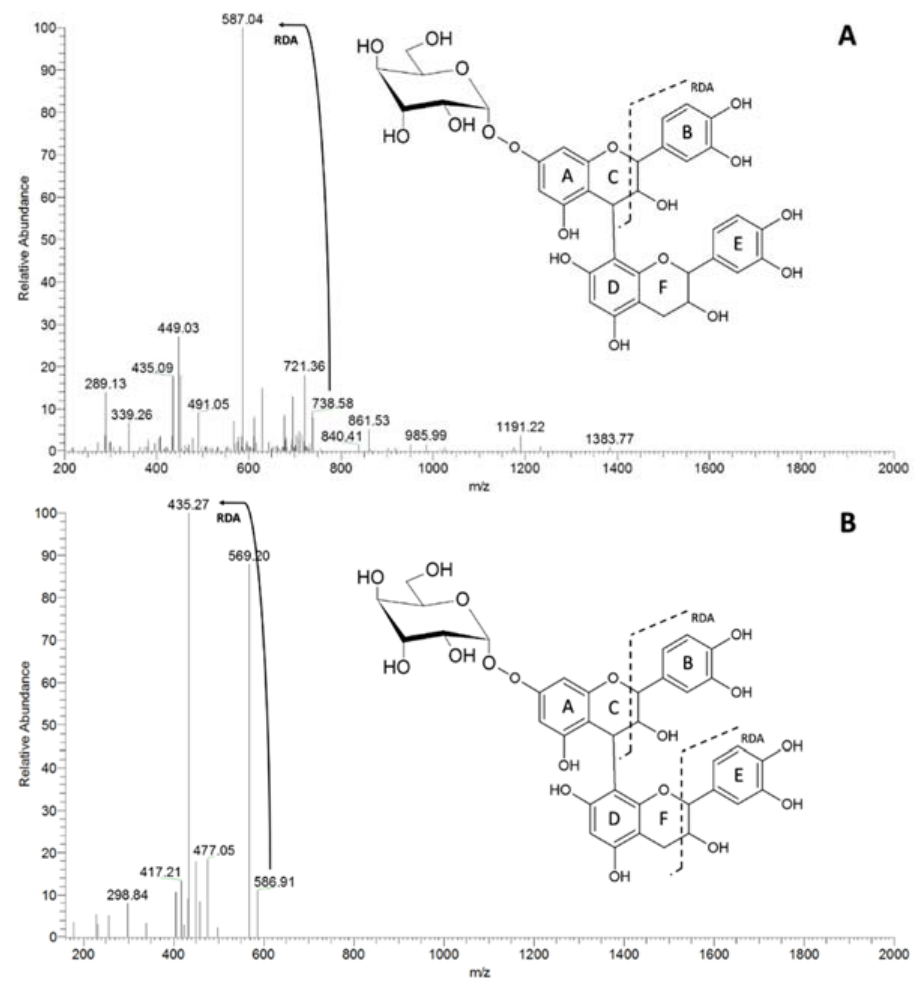

Figure 4. MS/MS spectra of the ion at $m / z 739$, evidencing the main patterns of fragmentation of hexosyl PAs. RDA = retro Dies-Alder. (A) $\mathrm{MS}^{2}$ spectrum of the precursor ion of $\mathrm{m} / z$ 739 $[\mathrm{M}-152-\mathrm{H}]^{-}$; (B) $\mathrm{MS}^{3}$ spectrum of the precursor ion of $m / z 739$ [M-152-152-H $]^{-}$. 
However, we found that this type of fragmentation pattern does not occur with molecules of higher molecular weight, such as catechin tetramers $\left(m / z\right.$ 1153). The $\mathrm{MS}^{2}$ spectrum of the precursor ion at $m / z 1153$ generated the product ion at $m / z 865[\mathrm{M}-288-\mathrm{H}]^{-}$, due to QM fragmentation (Figure 5). The $\mathrm{MS}^{3}$ spectrum of the precursor ion at $m / z 1153[\mathrm{M}-288-\mathrm{H}]^{-}$showed major product ions at $m / z$ 847, $m / z 739, m / z 587$ and $m / z 451$ (Figure 5). The product ion at $m / z 847$ was derived from the loss of water [M-18-H] ${ }^{-}$. The product ion at $m / z 739$ was due to HRF [M-126-H] ${ }^{-}$. HRF + RDA yielded the product ion at $m / z 587[\mathrm{M}-278-\mathrm{H}]^{-}$; and the product ion at $m / z 451$ was generated from a $\mathrm{QM}+\mathrm{HRF}$ fragmentation $[\mathrm{M}-414-\mathrm{H}]^{-}$. Figure 5 shows the fragmentation pathway proposed for the higher molecular weight molecules, which possessed mixed fragmentations that were not detected in smaller molecules.
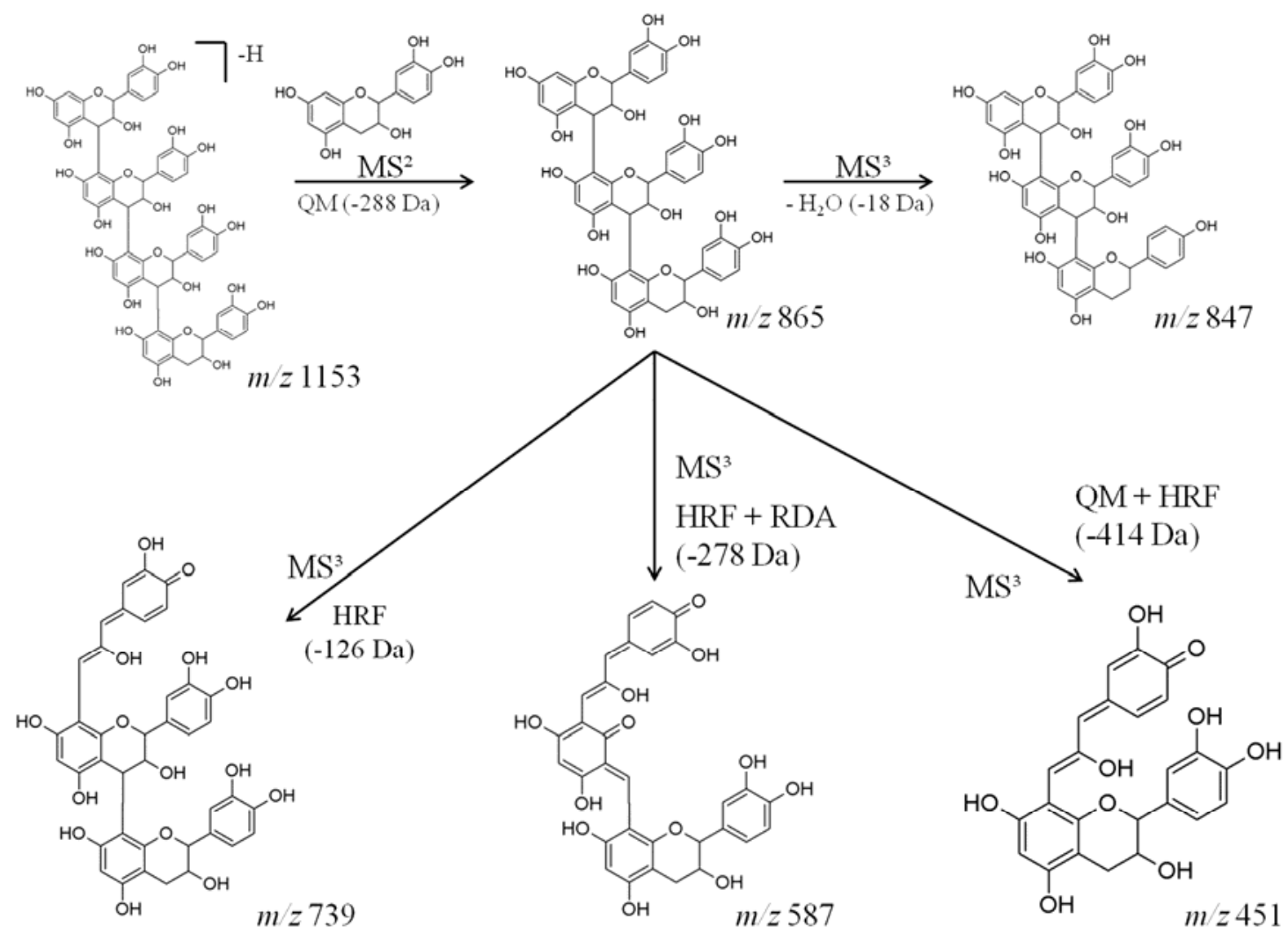

Figure 5. Fragmentation pathways of a possible tetramer proanthocyanidin found in AERM. The main fragmentation mechanisms involved are: HRF, RDA, and QM.

Although the acetone extract of $R$. mangle was composed mostly of catechin derivatives, other substances were detected. Quinic acid derivatives $(m / z 191)$ were detected in the negative mode. MS ${ }^{2}$ fragmentation of the precursor ion at $\mathrm{m} / z 515$ generated the product ion at $\mathrm{m} / \mathrm{z} 353$ [M-162-H] $^{-}$(Figure 6A, Table 1). The MS ${ }^{3}$ fragmentation of the precursor ion of $m / z 515$ produced the product ion of $m / z 191$ [M-162-162-H] ${ }^{-}$(Figure 6B, Table 1), which is characteristic of dicaffeoyl-quinic acids [26]. It is probable that these substances are produced owing to the biotic and abiotic stress conditions to which the plant is exposed in the ecosystem [26]. In addition, compounds in this class possess antioxidant, antiviral, anti-bactericidal, and anti-inflammatory effects, have been shown to reduce the risk of cardiovascular disease and type 2 diabetes, and have a beneficial role in Alzheimer's Disease [27]. To our knowledge, this class of substances has not been previously reported in the literature for the genus Rhizophora. 

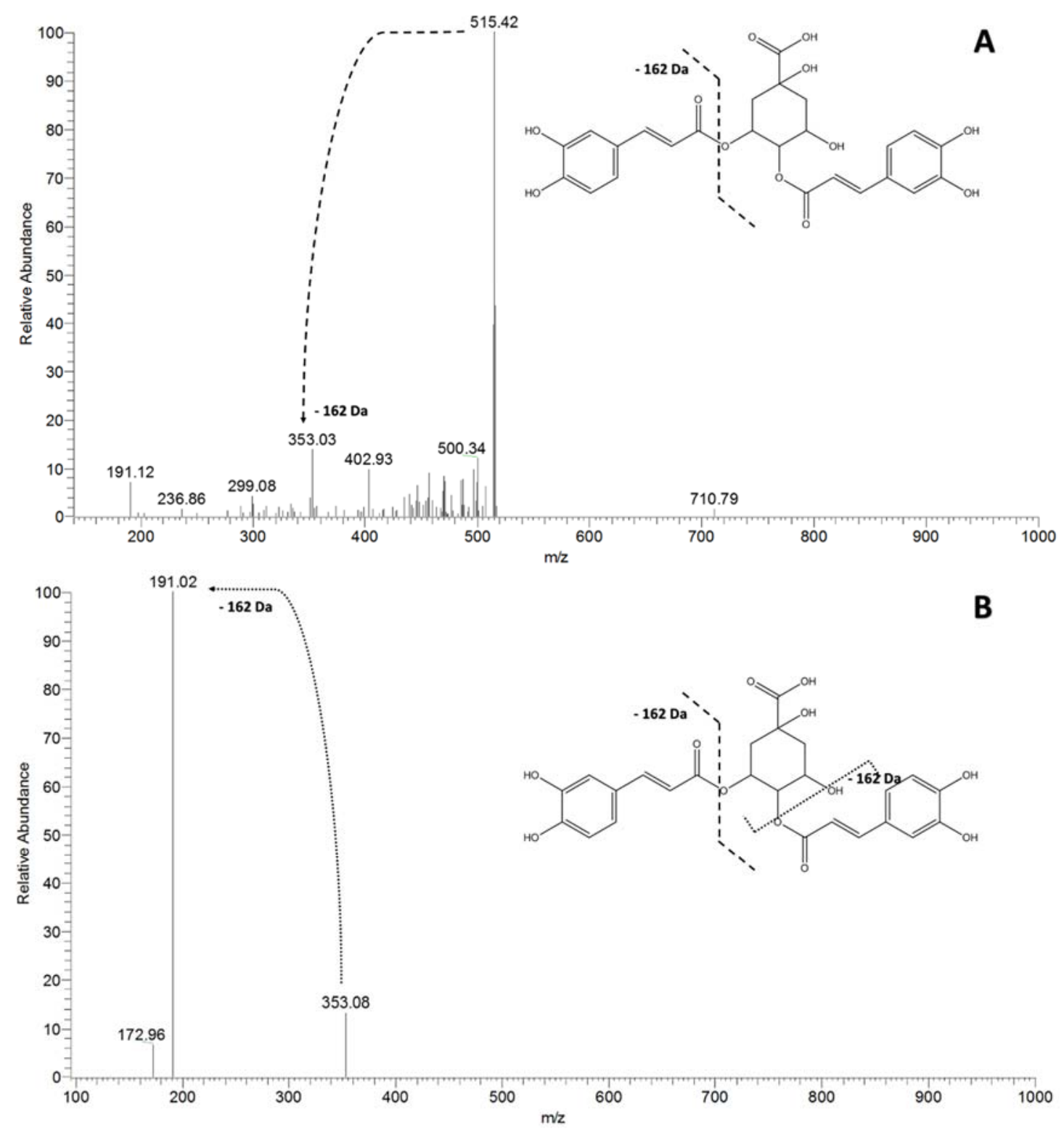

Figure 6. MS/MS spectrum of the precursor ion at $m / z 515$, evidencing the main patterns of fragmentation of dicaffeoyl-quinic acids. (A) The $\mathrm{MS}^{2}$ spectrum of the precursor ion at $515[\mathrm{M}-162-\mathrm{H}]^{-}$;

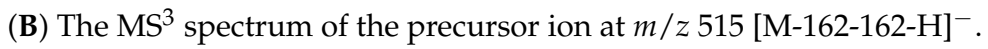

Another substance detected by FIA-ESI-IT-MS presented $m / z$ 609. The MS ${ }^{2}$ fragmentation of the precursor ion $m / z 609$ produced two major fragments. The ion at $m / z 463[\mathrm{M}-146-\mathrm{H}]^{-}$(Figure 7) was probably due to the loss of a deoxyhexose moiety, whereas the ion at $m / z 301$ [M-308-H] ${ }^{-}$(Figure 7) arose from the loss of a glycosidic hexose-deoxyhexose chain, which led us to propose the presence of rutin, a flavonoid commonly found in several plant families that has previously been detected in R. mangle extracts [28]. 


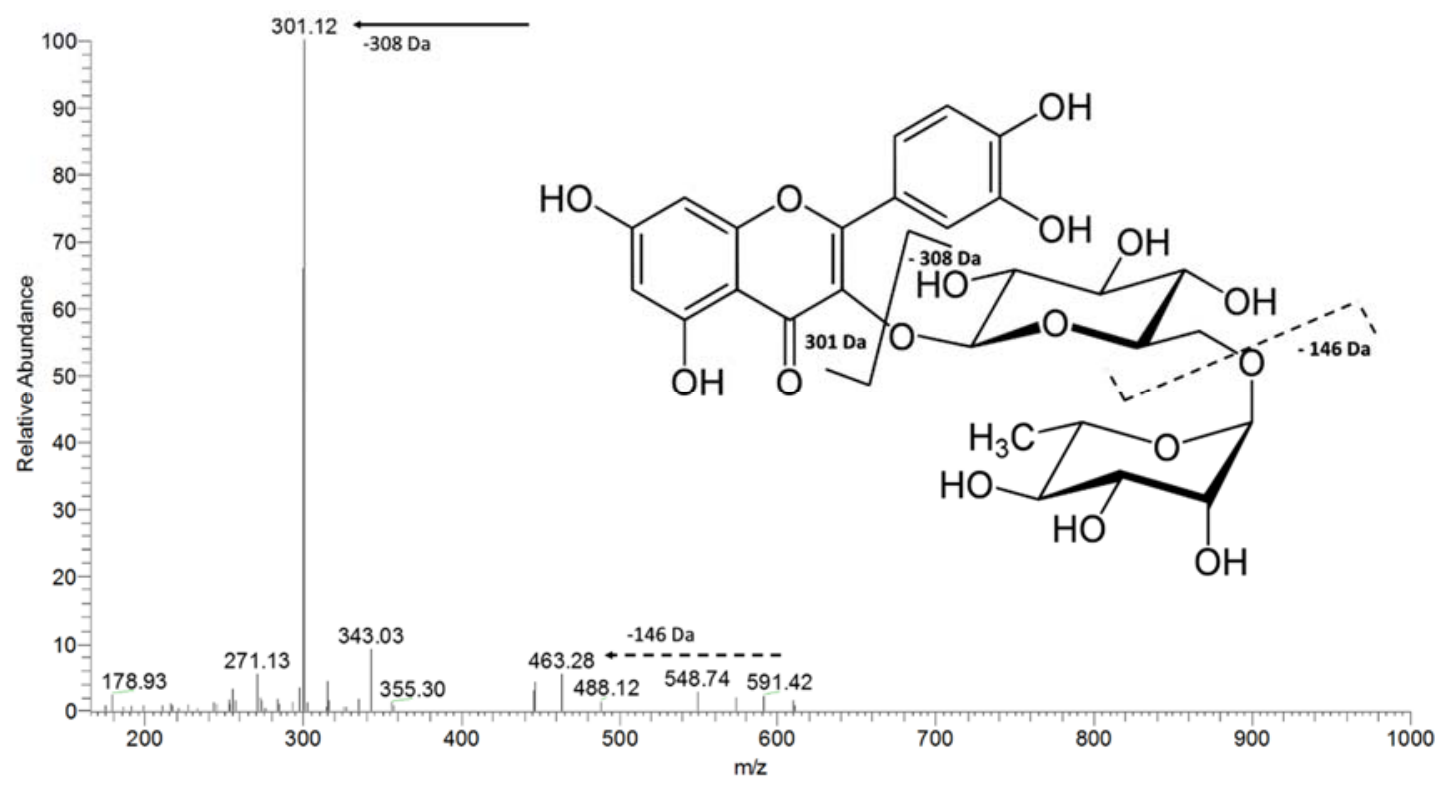

Figure 7. The $\mathrm{MS}^{2}$ spectrum of the ion at $m / z 609$, evidencing the main patterns of fragmentation of rutin.

\subsection{In Vitro Activities of the Extract}

The relatively stable organic radical 2,2'-azino-bis(3-ethylbenzothiazoline-6-sulphonic acid) $\left(\mathrm{ABTS}^{\bullet+}\right)$ has been widely used to determine the radical scavenging activity of different plant extracts [29]. The AERM demonstrated intense antioxidant activity $(608.8 \mu \mathrm{mol}$ Trolox/g). Zhang et al. (2010) [20] reported the powerful antioxidant activity of $R$. mangle and $R$. mucronata from the leaf ethanolic extracts using the, 2-diphenyl-1-picrylhydrazyl assay (DPPH) and attributed this effect to the large amount of condensed tannins present in the extract. Takara et al. (2008) [30] evaluated the antioxidant activity of the R. stylosa species and showed that the sugar moieties present in the condensed tannins further increase the efficiency of free-radical sequestration, which might occur in AERM.

The digestion of food starch and triglycerides in the gastrointestinal milieu is performed by amylases and lipases, respectively. Acarbose is a potent inhibitor of amylases, and delays the production of glucose helping to improve insulin resistance and glucose homeostasis in diabetic patients [31]. Similarly, orlistat, a pancreatic lipase inhibitor currently approved as an anti-obesity therapeutic, works by reducing the intestinal absorption of free fatty acids [32]. The presence of lipase and/or amylase inhibitors of plant origin has been demonstrated for different polyphenolic-rich plant species [33]. AERM inhibited lipase activity with an inhibitory concentration $\mathrm{IC}_{50}$ of $803 \mu \mathrm{g} / \mathrm{mL}$, while orlistat inhibits lipase with an $\mathrm{IC}_{50}$ of $27.4 \mu \mathrm{g} / \mathrm{mL}$ in the same set of assays. Alpha-amylase assay resulted in the inhibition of AERM activity at an $\mathrm{IC}_{50}$ of $19.0 \mu \mathrm{g} / \mathrm{mL}$, while acarbose inhibited amylase with an $\mathrm{IC}_{50}$ of $5.2 \mu \mathrm{g} / \mathrm{mL}$ (Figure 8). Tannins have been suggested as potent inhibitors of human salivary and porcine pancreatic $\alpha$-amylases [34,35], suggesting that PAs from AERM could be implicated in this potent inhibitory activity. In addition, it has been reported that PAs of cinnamon water extract inhibited the amyloid formation of Human islet amyloid polypeptide (hIAPP) in a dose-dependent manner. Proanthocyanidins affected the secondary structures of hIAPP and delayed the structural transition from unstructured coils to $\beta$-sheet-rich structures. The PAs are the major components of the AERM, the causes for the antidiabetic effect of the extract are considered [36]. 

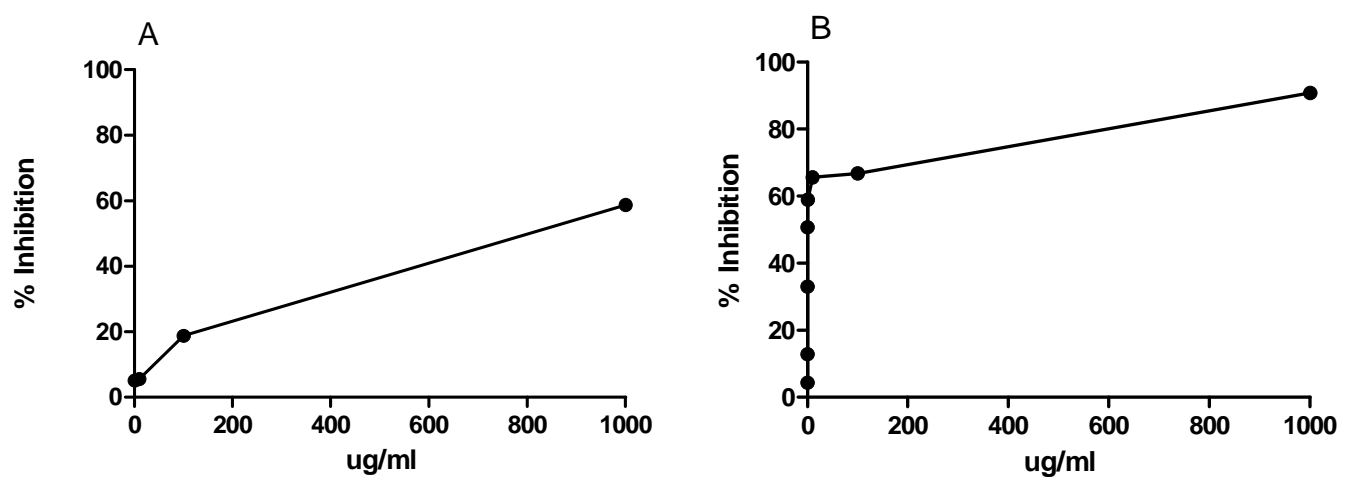

Figure 8. In vitro pancreatic lipase (A) and amylase (B) inhibition by AERM. Experiment was performed in triplicate. $\mathrm{IC}_{50}$ was calculated from curves using GraphPad Prism Software.

\subsection{Hepatoprotective and Insulin Sensitization after AERM Administration In Vivo}

Mice fed a high-fat diet (HFD) for 8 weeks became obese compared with mice fed a standard diet, as observed by the increase in final body weight and visceral and subcutaneous adipose tissue deposits (Table 2). An increase in liver weight was also observed in the obese mice, suggesting the presence of hepatic alterations associated with obesity (Table 2). Four-weeks treatment with AERM was not enough to significantly reduce the body weight gain and adiposity in HFD and control mice; however, liver weight was significantly reduced in obese mice treated with $R$. mangle compared with non-treated obese mice (Table 2).

Table 2. Body weight and body composition of control mice, control mice treated with AERM 5 $\mathrm{mg} \cdot \mathrm{kg}^{-1}$ (Control5) or $50 \mathrm{mg} \cdot \mathrm{kg}^{-1}$ (Control50), obese mice (HFD) and obese mice treated with AERM $5 \mathrm{mg} \cdot \mathrm{kg}^{-1}$ (HFD5) or $50 \mathrm{mg} \cdot \mathrm{kg}^{-1}$ (HFD50).

\begin{tabular}{|c|c|c|c|c|c|c|}
\hline Parameters & Control & Control5 & Control50 & HFD & HFD5 & HFD50 \\
\hline Body weight at 8 th week (g) & $42.2 \pm 1.4$ & $41.7 \pm 1.2$ & $43.0 \pm 1.8$ & $55.0 \pm 1.2 *$ & $52.0 \pm 2.0$ & $53.0 \pm 1.2$ \\
\hline Final body weight $(\mathrm{g})$ & $44.7 \pm 1.8$ & $45.2 \pm 1.6$ & $43.5 \pm 1.3$ & $61.2 \pm 2.4 *$ & $56.0 \pm 2.7$ & $55.2 \pm 1.3$ \\
\hline$\Delta$ Body weight $(\%)$ & $5.8 \pm 1.2$ & $8.2 \pm 1.5$ & $1.6 \pm 2.5$ & $9.8 \pm 2.6$ & $6.2 \pm 2.7$ & $4.2 \pm 2.2$ \\
\hline Food intake (kcal/day) & $14.3 \pm 1.1$ & $13.3 \pm 0.4$ & $12.0 \pm 0.4^{\#}$ & $25.5 \pm 1.1$ & $24.3 \pm 0.9$ & $23.4 \pm 1.9$ \\
\hline Epididimal fat $(\mathrm{g})$ & $1.8 \pm 0.3$ & $1.5 \pm 0.2$ & $1.5 \pm 0.1$ & $2.7 \pm 0.1 *$ & $2.9 \pm 0.2$ & $2.7 \pm 0.4$ \\
\hline Epididimal fat (\%) ${ }^{a}$ & $4.0 \pm 0.4$ & $3.4 \pm 0.3$ & $3.7 \pm 0.1$ & $4.4 \pm 0.1$ & $5.1 \pm 0.4$ & $5.1 \pm 0.8$ \\
\hline Subcutaneous fat (g) & $0.7 \pm 0.1$ & $0.5 \pm 0.1$ & $0.6 \pm 0.1$ & $1.3 \pm 0.1^{*}$ & $1.0 \pm 0.1$ & $1.2 \pm 0.2$ \\
\hline Subcutaneous fat (\%) ${ }^{a}$ & $1.6 \pm 0.2$ & $1.2 \pm 0.1$ & $1.5 \pm 0.1$ & $2.1 \pm 0.1 *$ & $1.8 \pm 0.3$ & $2.2 \pm 0.2$ \\
\hline Liver $(g)$ & $1.8 \pm 0.1$ & $1.9 \pm 0.1$ & $1.7 \pm 0.1$ & $3.0 \pm 0.3 *$ & $2.1 \pm 0.1^{\#}$ & $2.2 \pm 0.2^{\#}$ \\
\hline Liver $(\%)^{a}$ & $4.2 \pm 0.2$ & $4.2 \pm 0.1$ & $4.0 \pm 0.1$ & $4.9 \pm 0.3$ & $3.7 \pm 0.3^{\#}$ & $3.9 \pm 0.1^{\#}$ \\
\hline Gastrocnemius muscle (g) & $0.2 \pm 0.0$ & $0.2 \pm 0.0$ & $0.2 \pm 0.0$ & $0.2 \pm 0.0$ & $0.2 \pm 0.0$ & $0.2 \pm 0.0$ \\
\hline Gastrocnemius muscle (\%) ${ }^{a}$ & $0.5 \pm 0.1$ & $0.4 \pm 0.0$ & $0.5 \pm 0.0$ & $0.3 \pm 0.0$ & $0.4 \pm 0.0$ & $0.3 \pm 0.0$ \\
\hline
\end{tabular}

Interestingly, fasting blood levels of glucose and insulin were also reduced in obese mice treated with higher-dose AERM at $(50 \mathrm{mg} / \mathrm{kg})$, and these mice were partially more tolerant to insulin, as observed by the $k$ of insulin tolerance test (ITT) value and ITT curves (Table 3 and Figure 9). Serum total and low-density lipoprotein (LDL)-cholesterol were also reduced by AERM. Insulin resistance that results in hyperglycemia/hyperinsulinemia is routinely associated with obesity. Oral quercetin supplementation $(30 \mathrm{mg} / \mathrm{kg} /$ day) was not effective at inducing weight loss in HFD mice, but it was effective as an antidiabetic [37]. As demonstrated, water provided orally ad libitum with $0.5 \%$ of procyanidins from apple juice over 4 weeks to genetically obese mice resulted in the maintenance of body weight and adiposity. It also improved insulin resistance via the suppression of pro-inflammatory cytokines in the liver [38]. 
Table 3. Serum parameters and kITT of control mice, control mice treated with AERM $5 \mathrm{mg} \cdot \mathrm{kg}^{-1}$ (Control5) or $50 \mathrm{mg} \cdot \mathrm{kg}^{-1}$ (Control50), obese mice (HFD) and obese mice treated with AERM $5 \mathrm{mg} \cdot \mathrm{kg}^{-1}$ (HFD5) or $50 \mathrm{mg} \cdot \mathrm{kg}^{-1}$ (HFD50).

\begin{tabular}{lcccccc}
\hline \multicolumn{1}{c}{ Parameters } & Control & Control5 & Control50 & HFD & HFD5 & HFD50 \\
\hline Fasting glucose (mg/dL) & $166 \pm 5$ & $150 \pm 4$ & $152 \pm 5$ & $226 \pm 11^{*}$ & $201 \pm 22$ & $197 \pm 6^{\#}$ \\
Fasting insulin $(\mathrm{ng} / \mathrm{mL})$ & $106 \pm 13$ & $112 \pm 14$ & $207 \pm 16^{\#}$ & $176 \pm 34^{*}$ & $161 \pm 17$ & $127 \pm 9^{\#}$ \\
kITT & $5.4 \pm 0.3$ & $5.7 \pm 0.7$ & $5.0 \pm 0.5$ & $2.0 \pm 0.4^{*}$ & $2.6 \pm 0.8$ & $3.2 \pm 0.3^{\#}$ \\
Total cholesterol (mg/dL) & $174 \pm 2$ & $164 \pm 22^{\#}$ & $168 \pm 2$ & $203 \pm 9^{*}$ & $184 \pm 7$ & $180 \pm 4^{\#}$ \\
LDL-cholesterol (mg/dL) & $100 \pm 7$ & $98 \pm 6$ & $102 \pm 6$ & $144 \pm 10^{*}$ & $118 \pm 4^{\#}$ & $106 \pm 9^{\#}$ \\
HDL-cholesterol (mg/dL) & $57 \pm 4$ & $54 \pm 3$ & $52 \pm 1$ & $52 \pm 2$ & $50 \pm 1$ & $54 \pm 2$ \\
Triglycerides (mg/dL) & $187 \pm 22$ & $193 \pm 32$ & $201 \pm 24$ & $99 \pm 7^{*}$ & $98 \pm 5$ & $127 \pm 17$ \\
\hline
\end{tabular}

The results are expressed as the means \pm standard errors of the mean $(n=5) .{ }^{*} p<0.05$ when compared with control group and ${ }^{\#} p<0.05$ when compared with non-treated group.

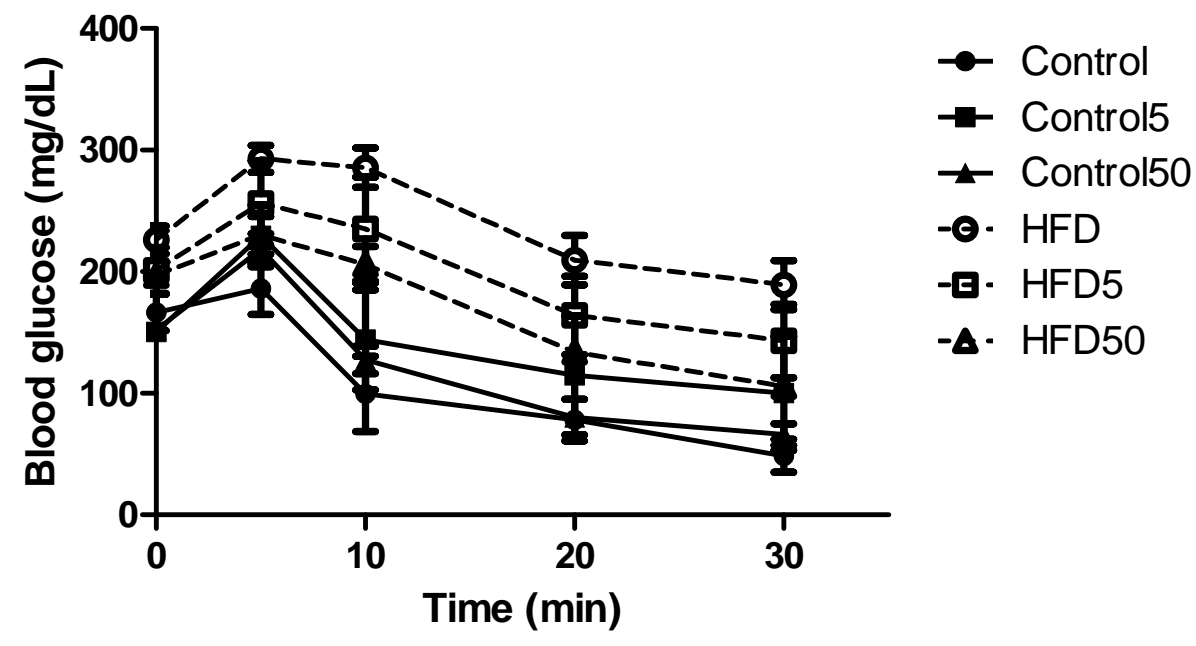

Figure 9. Blood glucose before (0) and after insulin administration in control mice, control mice treated with AERM $5 \mathrm{mg} \cdot \mathrm{kg}^{-1}$ (Control5) or control mice treated with AERM $50 \mathrm{mg} \cdot \mathrm{kg}^{-1}$ (Control50), obese mice (HFD), obese mice treated with AERM $5 \mathrm{mg} \cdot \mathrm{kg}^{-1}$ (HFD5) or obese mice treated with AERM $50 \mathrm{mg} \cdot \mathrm{kg}^{-1}$ (HFD50). The results are expressed as the means \pm standard errors of the mean $(n=5)$.

The analysis of body composition, as described above, revealed that obese mice treated with both AERM doses had reduced liver weight compared with non-treated obese mice (Table 2). Obese mice presented steatosis after receiving an HFD for 12 weeks; however, in mice treated with AERM at $50 \mathrm{mg} / \mathrm{kg}$, the area of hepatic steatosis and the triglycerides content were significantly reduced (Figure 10). Recently, it has been reported that catechins can improve the blood lipid profile, and to prevent the accumulation of fat in the liver on hyperlipidemic rats [39]. However, in Swiss mice fed an HFD for 12 weeks, no increase in the expression of hepatic pro-inflammatory cytokines (Interleukin (IL)-6, Tumor Necrosis Factor (TNF)) were detected (Figure 11). Feeding C57Bl6 mice an HFD for 12-weeks was unable to induce inflammatory markers or c-Jun N-terminal kinases (JNK) activation in liver. Hepatic inflammation was only observed when fructose or sucrose was added to the HFD [40]. Accumulation of hepatic triglycerides (steatosis) is the first step of NAFLD, and may be due the increased free fatty acid (FFA) supply, decreased FFA oxidation, increased de novo lipogenesis, and/or very low-density lipoprotein (VLDL)-triglyceride secretion [41]. Liver uptake of FFA is facilitated by cell-surface receptors, such as CD36/fatty acid translocase. The mRNA expression of CD36 in hepatocytes is normally low, but an important increase was observed in response to a HFD and following the activation of nuclear receptors, including peroxisome proliferator-activated receptor (PPAR) $-\gamma$ [42]. We observed a modulatory effect of AERM on the mRNA expression of liver PPAR- $\gamma$, which was associated with the inhibition of CD36 mRNA expression (Figure 11), 
suggesting that AERM down regulates CD36 mRNA via PPAR- $\gamma$ inhibition. Hepatic expression of Srebf1 and Ppard, which encode sterol regulatory-binding protein-1c (SREBP-1c), a regulator of de novo lipogenesis, or PPAR- $\alpha$, a regulator of FA oxidation, was not altered following AERM treatment. Herbal formulations containing the aqueous extract of Dolichos lablab, the aqueous extracts of Penthorum chinense, the ethanol extract of Solidago virgaurea, or the isolated flavonoid quercetin, could able to inhibit hepatic lipid accumulation through the downregulation of mRNA expression of CD36 [43-46]. Several studies have demonstrated that orlistat in the range $10-100 \mathrm{mg} / \mathrm{kg}$ can reduce liver weight, hepatic triglycerides, and serum triglycerides/cholesterol in mice fed a HFD [47-49]. AERM demonstrated in vitro anti-lipase activity, which was less potent than that of orlistat, but in vitro anti-amylase was more similar inhibited if compared to acarbose. In vivo administration of orlistat requires doses around $50 \mathrm{mg} / \mathrm{kg}$ to determine lowering serum triglycerides (TG) effects and probably it explain why we did not observe it in vivo with AERM. However, in vivo, acarbose is only effective at $40 \mathrm{mg} / \mathrm{kg} /$ day [50,51], suggesting that anti-amylase activity could be a role for glucose homeostasis and for the hepatoprotective effects of AERM.
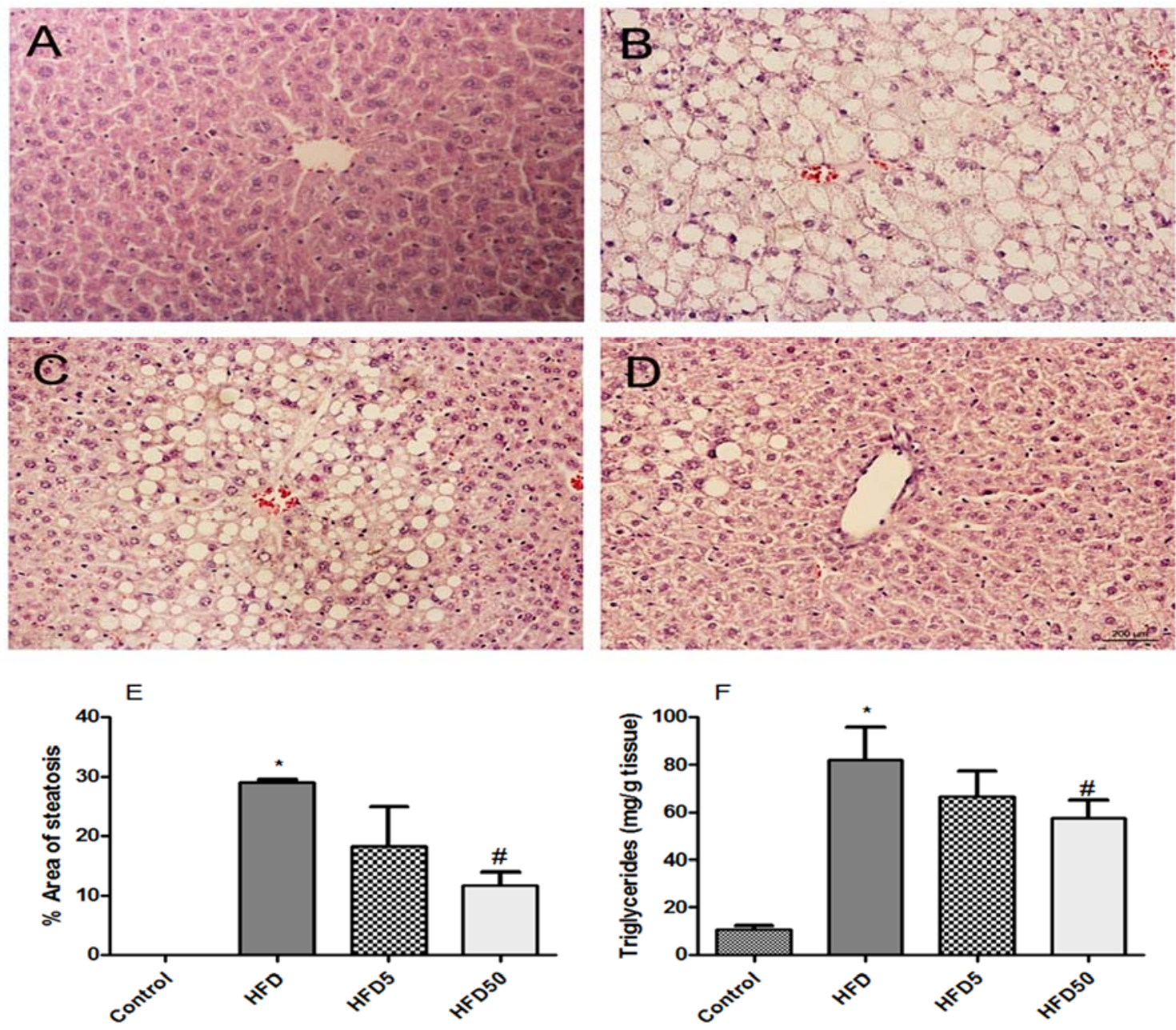

Figure 10. (A) Liver histology of control mice; (B) obese mice (HFD); (C) obese mice treated with AERM $5 \mathrm{mg} \cdot \mathrm{kg}^{-1}$ (HFD5); (D) obese mice treated with AERM $50 \mathrm{mg} \cdot \mathrm{kg}^{-1}$ (HFD50); (E) steatosis measurement; (F) triglycerides content. Hematoxylin-eosin staining of $5.0 \mu \mathrm{m}$ liver sections. Magnification: $200 \times$. Steatosis measurement in five random power fields of five mice per group. (E-F) The results are expressed as the means \pm standard errors of the mean $(n=5) .{ }^{*} p<0.01$ when compared with the control group and ${ }^{\#} p<0.05$ when compared with the HFD group. 

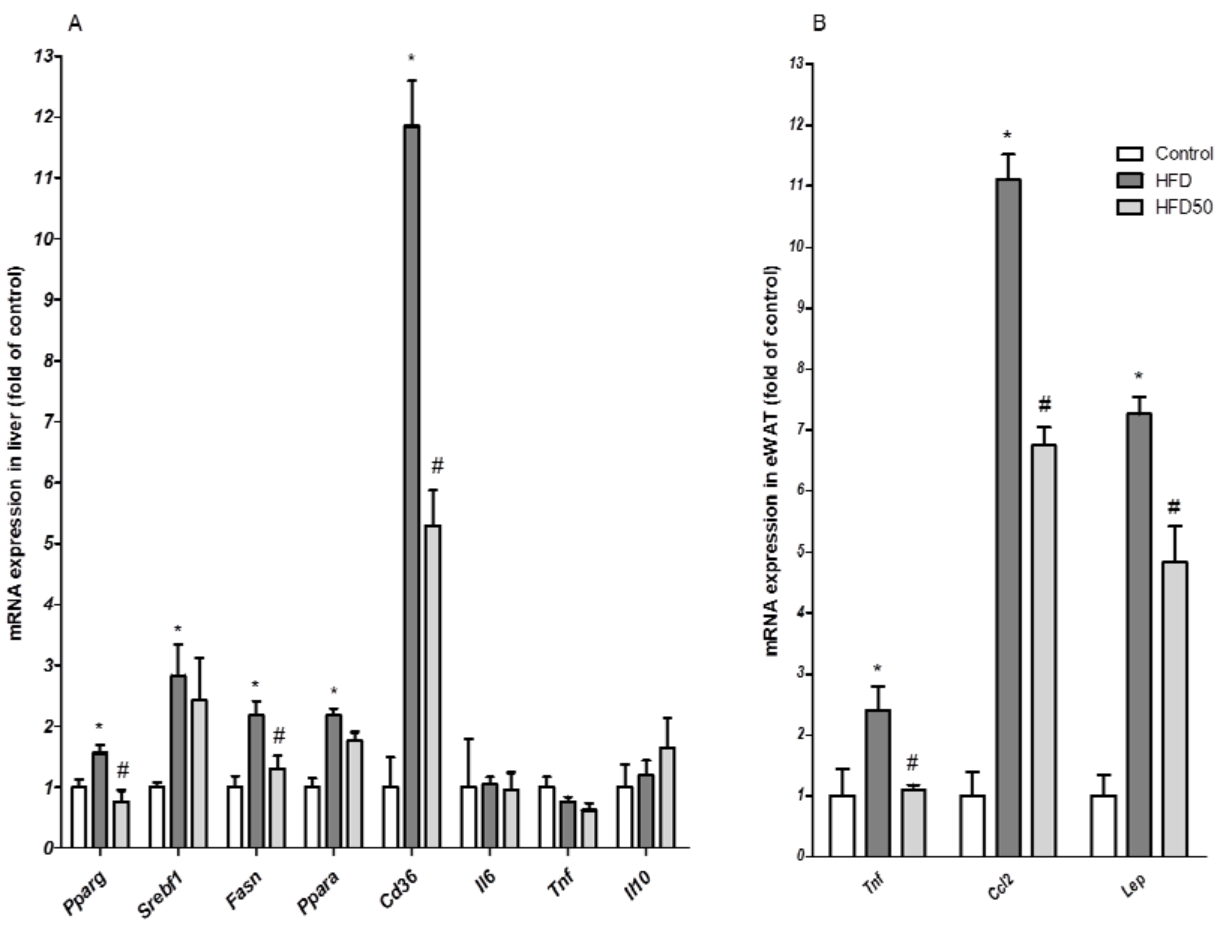

Figure 11. (A) mRNA expression in the liver and (B) adipose tissue of control mice (Control), obese mice (HFD) and obese mice treated with AERM $50 \mathrm{mg} \cdot \mathrm{kg}^{-1}$ (HFD50). The results are expressed as the means \pm standard errors of the mean $(n=5)$. ${ }^{*} p<0.05$ when compared with control group and \# $p<0.05$ compared with the HFD group.

Interestingly, mice treated with AERM presented reduced expression of pro-inflammatory genes but no reduction in adiposity compared with non-treated obese mice (Figure 6B), suggesting that AERM has anti-inflammatory activity, mitigating obesity-associated adipose tissue inflammation, which could contribute to reverse insulin resistance. A similar effect as previously described for dietary supplementation with grape-seed PAs [52] and isolated catechins [53]. However, we investigated the antioxidant effects of AERM by measuring malondialdehyde (MDA) as an index of lipid peroxidation [54] in the liver and adipose tissue of mice, and were unable to confirm that the antioxidant activity was maintained in vivo (data not shown).

Food ingestion was not different between treated and non-treated obese groups. However, the higher dose of AERM employed in our study was able to reduce the amount of food intake by the control group, as well as increase the basal insulin level (Table 2). Insulin can signal energy homeostasis to the central nervous system. Insulin and leptin levels are increased in individuals with obesity, but due to insulin resistance in these individuals, the satiety signal is dysregulated $[55,56]$. AERM-induced appetite suppression was only observed in lean mice, without insulin resistance, showing that the central anorexigenic action of this protein is being performed correctly; however, the mechanism(s) through which AERM increases insulin release should be further investigated. Oral administration of a tetrameric procyanidin from cacao, cinnamtannin A2, in lean mice resulted in incretin activity by increasing insulin release through mechanisms involving increased plasma levels of glucagon-like peptide (GLP)-1 [57].

\section{Materials and Methods}

\subsection{Sample Taxon}

The barks of Rhizophora mangle L. (Rhizophoraceae) were collected from the estuarine system of the ecological station at Juréia-Itatins (Peruíbe, São Paulo-Brazil-24 $25^{\prime} 40^{\prime \prime}$ S- $-47^{\circ} 05^{\prime} 20^{\prime \prime}$ W). Collection 
of the material was approved by prior authorization from the Brazilian authorities (IBAMA/MMA: 52497-1). A voucher specimen (no. 11459) has been deposited at the Herbarium HUSC of the Santa Cecilia University (Santos, São Paulo-Brazil).

\subsection{Chemical Characterization}

\subsubsection{Preparation of Plant Extract}

Fresh barks of $R$. mangle were washed, shade-dried, powdered in a knife mill, and sieved through a \#60 mesh sieve. The powder (50 g) was extracted with $0.5 \mathrm{~L}$ of acetone $(70 \% v / v)$ and macerated for 7 days at room temperature $\left(24^{\circ} \mathrm{C}\right)$, protected from light. The macerate was filtered through Whatman no.1 filter paper and concentrated in a rotary flash evaporator at a temperature not exceeding $35^{\circ} \mathrm{C}$. The extract $(7 \mathrm{~g}, 14 \%)$ was lyophilized and stored in amber bottles and placed into in a freezer $\left(-40^{\circ} \mathrm{C}\right)$. To minimize the interference of very high-order polymeric compounds, a SPE was performed. An aliquot $(10 \mathrm{mg})$ of the extract was submitted to the SPE using a RP18 cartridge, eluted with $\mathrm{H}_{2} \mathrm{O} / \mathrm{MeOH} 8: 2(v / v)(5 \mathrm{~mL})$. The eluate was filtered through the nylon membrane $(0.22 \mu \mathrm{m})$ and directly analyzed by chromatography and mass spectrometry.

\subsubsection{HPLC-PDA}

The chemical composition of AERM was investigated by high-performance liquid chromatography coupled to a Photodiode Array Detector (HPLC-PDA), using a Jasco (Tokyo, Japan) HPLC equipped with a PU-2089 quaternary solvent pump, a MD-2010 PAD, and an AS-2055 autosampler. The analytical column, maintained at room temperature $\left(25^{\circ} \mathrm{C}\right)$, was a Phenomenex Synergi Hydro RP18 (250 mm $\times 4.6 \mathrm{~mm} \mathrm{H} \times$ i.d.; $4 \mu \mathrm{m})$ with a Phenomenex security guard column $(4.0 \times 2.0 \mathrm{~mm})$. Phenolic acids, flavonoids, flavan-3-ols, and PA were separated using the mobile phase of water (eluent A) and acetonitrile (eluent B), solvent A containing $0.1 \%$ formic acid, with the following gradient program: 5-50\% B (30 min), 30-85\% B (30-35 min), isocratic 85\% B (45 $\mathrm{min})$, $85-100 \%$ B (45-70 $\mathrm{min})$, return to $5 \% \mathrm{~B}$ (2 $\mathrm{min})$, and the column was re-equilibrated under the initial conditions for $18 \mathrm{~min}$ before the next injection. The flow rate was $1.0 \mathrm{~mL} \cdot \mathrm{min}^{-1}$, and the total run time was $70 \mathrm{~min}$. EZChrom Elite Data System software (Chromatec, Idstein, Germany) was used for detection operation and data processing. Compounds were identified by comparing retention times and UV spectral analyses.

\subsubsection{FIA-ESI-IT-MS/MS}

Flow injection analysis (FIA) was performed using a Thermo Fisher Scientific ion trap mass spectrometer (San Jose, CA, USA) equipped with an electrospray ionization source. MS and MS/MS analyses in negative ion mode were selected after calibration infusing a standard solution of (+)-catechin $(1 \mu \mathrm{g} / \mathrm{mL}$ in methanol) at a flow rate of $5 \mu \mathrm{L} / \mathrm{min}$ under the following conditions: capillary voltage $-31 \mathrm{~V}$, spray voltage $5 \mathrm{kV}$, tube lens offset $75 \mathrm{~V}$, capillary temperature $300{ }^{\circ} \mathrm{C}$, sheath gas $\left(\mathrm{N}_{2}\right)$ flow rate 8 (arbitrary units). Negative ion mass spectra were recorded in the range $m / z$ 100-2000 Da. The first event was a full-scan mass spectrum to acquire data on ions in the $m / z$ range. The second scan event was an MS/MS experiment performed using a data-dependent scan carried out on deprotonated molecules from the compounds at collision energy of 25-30\% and activation time of $30 \mathrm{~ms}$. Data were acquired and processed using the Xcalibur software (version 2.2 SP1.48).

\subsection{In Vitro Assays}

\subsubsection{Trolox Equivalent Antioxidant Capacity (TEAC) Assay}

2,2'-azino-bis(3-ethylbenzothiazoline-6-sulphonic acid) (ABTS) and potassium persulfate were dissolved in distilled water to a final concentration of 7 and $2.45 \mathrm{mM}$ respectively. These two solutions were mixed, and the mixture was allowed to stand in the dark at room temperature $\left(24^{\circ} \mathrm{C}\right)$ for $16 \mathrm{~h}$ 
before use, to allow the production of ABTS radical $\left(\mathrm{ABTS}{ }^{+}\right)$. To study phenolic compounds, the ABTS radical solution was diluted with distilled water to obtain an absorbance of 1.00 at $734 \mathrm{~nm}$. AERM (final concentrations $0.0001-0.01 \mathrm{mg} / \mathrm{mL}$ ) or Trolox standards (final concentration 0-20 mM) were added to diluted $\mathrm{ABTS} \bullet^{+}$solution and the absorbance reading was taken 6 min after mixing, using a spectrophotometer. Results are presented as the ability of phenols to scavenge free-radical ABTS $\bullet^{+}$ (Trolox equivalent antioxidant capacity).

\subsubsection{Lipase Activity Assay}

Lipase activity was determined by measuring the release of p-nitrophenol from p-nitrophenyl palmitate (4-NPP) via a spectrophotometric method at $405 \mathrm{~nm}$. Lipase $(10 \mathrm{mg} / \mathrm{mL})$ from porcine pancreas type II (Sigma, St. Louis, MO, USA) was dissolved in reaction buffer $50 \mathrm{mM}$ Tris-HCl $\mathrm{pH} 8.0$, and then centrifuged at $5000 \mathrm{~g}$ for $5 \mathrm{~min}$ to remove the insoluble components. 4-NPP was dissolved in 1:9 $\mathrm{v} / \mathrm{v}$ isopropanol:reaction buffer $(50 \mathrm{mM}$ Tris- $\mathrm{HCl} \mathrm{pH} 8,0$ containing $0.1 \%$ Arabic gum and $0.4 \%$ de triton $x-100)$. The final reaction mixture was 1:2:1 $v / v$ AERM:pancreatic lipase solution:4-NPP $(10 \mathrm{mM})$ and was added into wells of a 96-well microplate and incubated at $37^{\circ} \mathrm{C}$ for $20 \mathrm{~min}$, after which the amount of 4-nitrophenol released was measured. Orlistat was used as a positive control. Each experiment was performed in triplicate. Lipase inhibition was expressed as percentage and the $\mathrm{IC}_{50}$ was calculated by using GraphPad Prism Software (version 5.01).

\subsubsection{Alpha-Amylase Activity Assay}

$\alpha$-amylase activity was quantified by the reduction of 3,5-dinitrosalicylic acid to 3-amino-5-nitrosalicylic acid. $\alpha$-amylase $(10 \mathrm{mg} / \mathrm{mL})$ from porcine pancreas type VI-B (Sigma St. Louis, MO, USA) was dissolved in $50 \mathrm{mM}$ Tris- $\mathrm{HCl}$ buffer, $\mathrm{pH}$ 7.0, containing $\mathrm{NaCl} 38 \mathrm{mmol} / \mathrm{L}$ and $\mathrm{CaCl}_{2} 0.1 \mathrm{mmol} / \mathrm{L}$. The reaction included $0.1 \%$ potato starch $(w / v)$ as substrate, incubated at $37^{\circ} \mathrm{C}$ for 20 min with AERM and $\alpha$-amylase solution. The reaction was interrupted with the addition of 3,5-dinitrosalicylic acid (DNS), heated at $100^{\circ} \mathrm{C}$ for $5 \mathrm{~min}$, prior to quantification by spectrophotometry at $540 \mathrm{~nm}$. Activity was calculated using a glucose standard curve as a reference. Acarbose was used as a positive control. The experiment was carried out in triplicate. $\alpha$-amylase inhibition was expressed as percentage of inhibition and the $\mathrm{IC}_{50}$ was calculated using GraphPad Prism Software (version 5.01).

\subsection{Experimental Model of Diet-Induced Obesity}

\subsubsection{Animals}

Swiss male mice, specific-pathogen free, were obtained from the Multidisciplinary Center for Biological Research (CEMIB; State University of Campinas, Campinas, SP, Brazil). Experiments were performed in accordance with the principles outlined by the National Council for the Control of Animal Experimentation (CONCEA, Brazilia, Brazil) and received approval from the Ethics Committee of São Francisco University, Bragança Paulista, SP, Brazil (Protocol 001.02.16). Animals were maintained on a 12:12 $\mathrm{h}$ artificial light-dark cycle under controlled humidity and temperature.

\subsubsection{Diet-Induced Obesity and R. mangle Treatment}

Mice (six-week-old) were maintained on commercial chow (Control; $5 \%$ energy from fat) or HFD (60\% energy from fat), as previously described [56]. Body weight was assessed weekly. After 8 weeks, the control and HFD animals were randomly divided into groups ( $n=5$ each). During the next 4 weeks, mice received 5 or $50 \mathrm{mg} / \mathrm{kg}$ daily of AERM by oral gavage, dissolved in filtered tap water adjusted in a final volume of $4 \mathrm{~mL} / \mathrm{kg}$. Untreated groups received only water by gavage. Food intake was monitored by subtracting the amount of food consumed from the volume offered to the animals during AERM treatment. 


\subsubsection{Blood Glucose Levels and Insulin Tolerance Tests}

The insulin tolerance test was performed twenty-four hours before the end of the protocol [58], in which after $6 \mathrm{~h}$ of fasting, blood samples were collected from the tails of the mice to measure basal blood glucose using a glucometer (Accutrend Plus, Roche Diagnostics, Mannheim, Germany). Insulin $(1.5 \mathrm{U} / \mathrm{kg})$ was administered intraperitoneally and glucose blood was measured after 5, 10, 20 and $30 \mathrm{~min}$. Results were calculated using the formula $0.693 / \mathrm{t} 1 / 2$ and expressed as $\mathrm{kITT}$, which the glucose $\mathrm{t} 1 / 2$ was calculated from the slope of the least-square analysis during the linear decay phase.

\subsubsection{Necropsy and Sample Collection}

Mice were fasted overnight and anesthetized by xylazine/ketamine overdose $(0.1 \mathrm{~mL} / 30 \mathrm{~g}$ body weight of $1: 1 v / v$ of $2 \%$ xylazine and $10 \%$ ketamine). Blood was collected by cardiac puncture. Adipose tissue deposits (epididymis and subcutaneous), liver, and gastrocnemius muscle were carefully dissected, weighed, and expressed as a percentage of body weight (b.w.). Liver and visceral adipose samples were collected and stored at $-80^{\circ} \mathrm{C}$ for further analyses.

\subsubsection{Hepatic Analyses}

Hydrated $5.0 \mu \mathrm{m}$ sections of paraformaldehyde-fixed, paraffin-embedded liver specimens were stained using hematoxylin and eosin stain to evaluate the presence of liver steatosis. Steatosis was quantified by counting steatosis (macrovesicular and microvesicular) against a grid of 144 points. For the total lipid extractions, liver samples were homogenized in $\mathrm{NaCl} 0.9 \%$, and then a chloroform and methanol mixture (2:1 $v / v)$ was added [59]. The chloroform layer was collected, dried under $\mathrm{N}_{2}$, and reconstituted in PBS buffer. Triglycerides and total cholesterol were measured using a commercial kit (LaborLab, MG, Brazil).

\subsubsection{Serum Analyses}

Serum triglycerides and total LDL and high-density lipoprotein (HDL) cholesterol were measured using commercial kits (LaborLab, MG, Brazil). Insulin was quantified using a Milliplex kit (Merck Millipore, Burlington, MA, USA) [60].

\subsubsection{Quantitative Real-Time Polymerase Chain Reaction (qPCR)}

The relative expression of genes in the liver and adipose tissue samples were quantified by real-time polymerase chain reaction (PCR) as described previously [58]. All data (analyzed by the $\Delta \Delta \mathrm{Ct}$ method) were normalized to a control gene (18S) and represented as fold change with respect to the Control group. Primers used are listed in Table 4.

Table 4. Primers used for real-time PCR.

\begin{tabular}{ccc}
\hline Gene & Primer & Sequence $\left(\mathbf{5}^{\prime} \rightarrow \mathbf{3}^{\prime}\right)$ \\
\hline Pparg & Sense & GATGGAAGACCACTCGCATT \\
& Antisense & AACCATTGGGTCAGCTCTTG \\
\hline Ppara & Sense & AGAAGTTGCAGGAGGGGATT \\
& Antisense & TTGAAGCAGCTTYGGGAAGA \\
\hline Srebf1 & Sense & GTGAGCCTGACAAGCAATCA \\
& Antisense & GGTGCCTACAGAGCAAGAGG \\
\hline Cd36 & Sense & ATTCTCATGCCAGTCGGAGA \\
& Antisense & TGGCTTTTCACATCAAAGA \\
\hline Tnf & Sense & TAGCCAGGAGGGAGAACAGA \\
& Antisense & TTTTCTGGAGGGAGATGTGG \\
\hline$C c l 2$ & Sense & CCCAATGAGTAGGCTGGAGA \\
& Antisense & TCTGGACCCATTCCTTCTTG \\
\hline
\end{tabular}


Table 4. Cont.

\begin{tabular}{ccc}
\hline Gene & Primer & Sequence $\left(\mathbf{5}^{\prime} \rightarrow \mathbf{3}^{\prime}\right)$ \\
\hline Lep & Sense & CTATGCCACCTTGGTCACCT \\
& Antisense & ACCAAACCAAGCATTTTGC \\
\hline$I l 10$ & Sense & ATCGATTTCTCCCCTGTGAA \\
& Antisense & TTCATGGCCTTGTAGACACCT \\
\hline \multirow{2}{*}{ St6 } & Sense & TCTCTGGGAAATCGTGGAA \\
& Antisense & TTCTGCAAGTGCATCATCG \\
\hline Fasn & Sense & CACAGATGATGACAGGAGATGGA \\
& Antisense & TCGGAGTGAGGCTGGGTTGATA \\
\hline $18 s$ & Sense & AAACGGCTACCACATCCAAG \\
& Antisense & CAATTACAGGGCCTCGAAAG \\
\hline
\end{tabular}

\subsection{Statistical Analyses}

The results were expressed as the means \pm standard errors of the mean. Statistically significant differences were determined using analysis of variance (ANOVA) followed by Dunnett's test for multiple comparisons, using GraphPad InStat (GraphPad Software, Inc., La Jolla, CA, USA). $p$ Values $<0.05$ were considered significant.

\section{Conclusions}

In summary, these data provide evidence for the presence of three PA series, from one to four catechin moieties and their glycosylated forms, as well as phenolic acids and flavonoids, in the acetonic extract of $R$. mangle barks, which displayed anti-lipase, and anti-amylase activity in vitro. These compounds displayed an intense effect on the lipid metabolism and therefore help in the comorbidities associated with diabetes and obesity. in vivo, $R$. mangle bark extracts displayed hepatoprotective effects associated with the improvement of insulin resistance and potential effects upon adipose tissue inflammation associated with obesity. Taken together, these results support traditional knowledge of the use of $R$. mangle for the treatment of type 2 diabetes and reveal that bark extract has potential for the treatment of NAFLD and for the management of obesity-associated alterations.

Author Contributions: L.M.d.S.M.: lead author, manuscript writing, and execution of all chemical analysis. P.S.S., C.C.R., C.R.e.P.C., N.d.S.L., D.K.T.M, A.G.: experimental and statistical analysis; D.C.M.: antioxidant analysis and help in the discussion; A.G., C.Q.d.R., V.V.d.R. and W.V.: Guiding the work and supervising the experiments.

Funding: Fundação de Amparo a Pesquisa do Estado de São Paulo-FAPESP" for fundings (2009/52237-9) and fellowships (2014/23951-3).

Acknowledgments: This work was supported by "Fundação de Amparo a Pesquisa do Estado de São Paulo-FAPESP" for fundings (2009/52237-9), (2018/16388-1) and fellowships (2014/23951-3).

Conflicts of Interest: The authors declare no conflict of interest.

\section{Abbreviations}

ABTS 2,2'-azino-bis(3-ethylbenzothiazoline-6-sulphonic acid)

AERM Acetonic extract of Rhizophora mangle barks

DPPH 2,2-diphenyl-1-picrylhydrazyl

FA Formic acid

FFA Free-fat-acid

HFD High-fat diet

HPLC-PDA High-performance liquid chromatography coupled to photodiode array

HRF Heterocyclic ring fission

FIA-ESI-IT-MS Flow injection analysis electrospray-ion trap mass spectrometry

kiTT Insulin tolerance test 


$\begin{array}{ll}m / z & \text { mass/charge ratio } \\ \text { NAFLD } & \text { Non-alcoholic fatty liver disease } \\ \text { Pas } & \text { Proanthocyanidins } \\ \text { PCR } & \text { Polymerase chain reaction } \\ \text { RDA } & \text { Retro Diels-Alder } \\ \text { ROS } & \text { Reactive oxygen species } \\ \text { SPE } & \text { Solid-phase extraction } \\ \text { T2D } & \text { Type 2 diabetes } \\ \text { TEAC } & \text { Trolox equivalent antioxidant activity } \\ \text { QM } & \text { Quinone-methide }\end{array}$

\section{References}

1. Cordeiro, C.; Costa, T. Evaluation of solid residues removed from a mangrove swamp in the São Vicente Estuary, SP, Brazil. Mar. Pollut. Bull. 2010, 60, 1762-1767. [CrossRef] [PubMed]

2. Nebula, M.; Harisankar, H.; Chandramohanakumar, N. Metabolites and bioactivities of Rhizophoraceae mangroves. Nat. Prod. Bioprospect. 2013, 3, 207-232. [CrossRef]

3. Zhang, L.; Mao, W.; Guo, X.; Wu, Y.; Li, C.; Lu, Z.; Su, G.; Li, X.; Liu, Z.; Guo, R. Ginkgo biloba extract for patients with early diabetic nephropathy: A systematic review. Evid. Based Complement. Altern. Med. 2013, 2013, 17. [CrossRef]

4. Valdivia-Correa, B.; Gómez-Gutiérrez, C.; Uribe, M.; Méndez-Sánchez, N. Herbal medicine in Mexico: A cause of hepatotoxicity. A critical review. Int. J. Mol. Sci. 2016, 17, 235. [CrossRef] [PubMed]

5. Andrade-Cetto, A.; Heinrich, M. Mexican plants with hypoglycaemic effect used in the treatment of diabetes. J. Ethnopharmacol. 2005, 99, 325-348. [CrossRef] [PubMed]

6. Alarcon-Aguilara, F.; Roman-Ramos, R.; Perez-Gutierrez, S.; Aguilar-Contreras, A.; Contreras-Weber, C.; Flores-Saenz, J. Study of the anti-hyperglycemic effect of plants used as antidiabetics. J. Ethnopharmacol. 1998, 61, 101-110. [CrossRef]

7. World Health Organization. Global Report on Diabetes; World Health Organization: Geneva, Switzerland, 2016; ISBN 92-4-156525-X.

8. Associação Brasileira para Estudo da Obesidade e da Síndrome Metabólica (ABESO). Mapa da Obesidade; Brazilian Association for Obesity Study: São Paulo, Brazil, 2017.

9. Zhang, Y.; Feng, F.; Chen, T.; Li, Z.; Shen, Q.W. Antidiabetic and antihyperlipidemic activities of Forsythia suspensa (Thunb.) Vahl (fruit) in streptozotocin-induced diabetes mice. J. Ethnopharmacol. 2016, 192, 256-263. [CrossRef] [PubMed]

10. Choudhury, H.; Pandey, M.; Hua, C.K.; Mun, C.S.; Jing, J.K.; Kong, L.; Ern, L.Y.; Ashraf, N.A.; Kit, S.W.; Yee, T.S. An update on natural compounds in the remedy of diabetes mellitus: A systematic review. J. Tradit. Complement. Med. 2017, 8, 361-376. [CrossRef] [PubMed]

11. Azman, A.-S.; Othman, I.; Saraswati, S.V.; Chan, K.-G.; Lee, L.-H. Mangrove rare actinobacteria: Taxonomy, natural compound, and discovery of bioactivity. Front. Microbiol. 2015, 6, 856. [CrossRef] [PubMed]

12. de Faria, F.M.; Luiz-Ferreira, A.; Socca, E.A.R.; de Almeida, A.C.A.; Dunder, R.J.; Manzo, L.P.; da Silva, M.A.; Vilegas, W.; Rozza, A.L.; Pellizzon, C.H. Effects of Rhizophora mangle on experimental colitis induced by TNBS in rats. Evid. Based Complement. Altern. Med. 2012, 2012, 11. [CrossRef] [PubMed]

13. Thring, T.S.; Hili, P.; Naughton, D.P. Antioxidant and potential anti-inflammatory activity of extracts and formulations of white tea, rose, and witch hazel on primary human dermal fibroblast cells. J. Inflamm. 2011, 8, 27. [CrossRef] [PubMed]

14. He, F.; Pan, Q.-H.; Shi, Y.; Duan, C.-Q. Biosynthesis and genetic regulation of proanthocyanidins in plants. Molecules 2008, 13, 2674-2703. [CrossRef] [PubMed]

15. Jayarathne, S.; Koboziev, I.; Park, O.-H.; Oldewage-Theron, W.; Shen, C.-L.; Moustaid-Moussa, N. Anti-inflammatory and anti-obesity properties of food bioactive components: Effects on adipose tissue. Prev. Nutr. Food Sci. 2017, 22, 251-262. [CrossRef] [PubMed]

16. de-Faria, F.M.; Almeida, A.C.A.; Luiz-Ferreira, A.; Takayama, C.; Dunder, R.J.; da Silva, M.A.; Salvador, M.J.; Abdelnur, P.V.; Eberlin, M.N.; Vilegas, W. Antioxidant action of mangrove polyphenols against gastric 
damage induced by absolute ethanol and ischemia-reperfusion in the rat. Sci. World J. 2012, 2012. [CrossRef] [PubMed]

17. Rohr, G.E.; Meier, B.; Sticher, O. Evaluation of different detection modes for the analysis of procyanidins in leaves and flowers of Crataegus spp. Part I. Diode array and electrochemical detection. Phytochem. Anal. 2000, 11, 106-112. [CrossRef]

18. Ravikumar, S.; Inbaneson, S.J.; Suganthi, P.; Venkatesan, M.; Ramu, A. Mangrove plants as a source of lead compounds for the development of new antiplasmodial drugs from South East coast of India. Parasitol. Res. 2011, 108, 1405-1410. [CrossRef] [PubMed]

19. Oo, C.W.; Pizzi, A.; Pasch, H.; Kassim, M.J. Study on the structure of mangrove polyflavonoid tannins with MALDI-TOF mass spectrometry. J. Appl. Polym. Sci. 2008, 109, 963-967. [CrossRef]

20. Zhang, L.-L.; Lin, Y.-M.; Zhou, H.-C.; Wei, S.-D.; Chen, J.-H. Condensed tannins from mangrove species Kandelia candel and Rhizophora mangle and their antioxidant activity. Molecules 2010, 15, 420-431. [CrossRef] [PubMed]

21. Li, H.-J.; Deinzer, M.L. Tandem mass spectrometry for sequencing proanthocyanidins. Anal. Chem. 2007, 79, 1739-1748. [CrossRef] [PubMed]

22. Fulcrand, H.; Mané, C.; Preys, S.; Mazerolles, G.; Bouchut, C.; Mazauric, J.-P.; Souquet, J.-M.; Meudec, E.; Li, Y.; Cole, R.B. Direct mass spectrometry approaches to characterize polyphenol composition of complex samples. Phytochemistry 2008, 69, 3131-3138. [CrossRef] [PubMed]

23. Maldini, M.; Montoro, P.; Piacente, S.; Pizza, C. ESI-MS, ESI-MS/MS fingerprint and LC-ESI-MS analysis of proathocyanidins from Bursera simaruba Sarg bark. Nat. Prod. Commun. 2009, 4, 1671-1674. [PubMed]

24. Rodrigues, C.M.; Rinaldo, D.; dos Santos, L.C.; Montoro, P.; Piacente, S.; Pizza, C.; Hiruma-Lima, C.A.; Brito, A.R.; Vilegas, W. Metabolic fingerprinting using direct flow injection electrospray ionization tandem mass spectrometry for the characterization of proanthocyanidins from the barks of Hancornia speciosa. Rapid Commun. Mass Spectrom. 2007, 21, 1907-1914. [CrossRef] [PubMed]

25. Tala, V.R.S.; Candida da Silva, V.; Rodrigues, C.M.; Nkengfack, A.E.; Campaner dos Santos, L.; Vilegas, W. Characterization of proanthocyanidins from parkia biglobosa (JACQ.) G. Don.(Fabaceae) by flow injection analysis-Electrospray ionization ion trap tandem mass spectrometry and liquid chromatography/electrospray ionization mass spectrometry. Molecules 2013, 18, 2803-2820. [CrossRef] [PubMed]

26. Gouveia, S.C.; Castilho, P.C. Validation of a HPLC-DAD-ESI/MS n method for caffeoylquinic acids separation, quantification and identification in medicinal Helichrysum species from Macaronesia. Food Res. Int. 2012, 45, 362-368. [CrossRef]

27. Farah, A.; Monteiro, M.; Donangelo, C.M.; Lafay, S. Chlorogenic acids from green coffee extract are highly bioavailable in humans. J. Nutr. 2008, 138, 2309-2315. [CrossRef] [PubMed]

28. Kandil, F.; Grace, M.; Seigler, D.; Cheeseman, J. Polyphenolics in Rhizophora mangle L. leaves and their changes during leaf development and senescence. Trees 2004, 18, 518-528. [CrossRef]

29. Tirzitis, G.; Bartosz, G. Determination of antiradical and antioxidant activity: Basic principles and new insights. Acta Biochim. Pol. 2010, 57, 139-142. [PubMed]

30. Takara, K.; Kuniyoshi, A.; Wada, K.; Kinjyo, K.; Iwasaki, H. Antioxidative flavan-3-ol glycosides from stems of Rhizophora stylosa. Biosci. Biotechnol. Biochem. 2008, 72, 2191-2194. [CrossRef] [PubMed]

31. Kim, M.-J.; Lee, S.-B.; Lee, H.-S.; Lee, S.-Y.; Baek, J.-S.; Kim, D.; Moon, T.-W.; Robyt, J.F.; Park, K.-H. Comparative study of the inhibition of $\alpha$-glucosidase, $\alpha$-amylase, and cyclomaltodextrin glucanosyltransferase by acarbose, isoacarbose, and acarviosine-glucose. Arch. Biochem. Biophys. 1999, 371, 277-283. [CrossRef] [PubMed]

32. Tiss, A.; Ransac, S.; Lengsfeld, H.; Hadvàry, P.; Cagna, A.; Verger, R. Surface behaviour of bile salts and tetrahydrolipstatin at air/water and oil/water interfaces. Chem. Phys. Lipids 2001, 111, 73-85. [CrossRef]

33. Martinez-Gonzalez, A.I.; Díaz-Sánchez, Á.G.; Rosa, L.A.; Vargas-Requena, C.L.; Bustos-Jaimes, I. Polyphenolic compounds and digestive enzymes: In vitro non-covalent interactions. Molecules 2017, 22, 669. [CrossRef] [PubMed]

34. Kato, C.G.; Gonçalves, G.D.A.; Peralta, R.A.; Seixas, F.A.V.; de Sá-Nakanishi, A.B.; Bracht, L.; Comar, J.F.; Bracht, A.; Peralta, R.M. Inhibition of $\alpha$-amylases by condensed and hydrolysable tannins: Focus on kinetics and hypoglycemic actions. Enzym. Res. 2017, 2017, 12. [CrossRef] [PubMed] 
35. Kato, E.; Kushibiki, N.; Inagaki, Y.; Kurokawa, M.; Kawabata, J. Astilbe thunbergii reduces postprandial hyperglycemia in a type 2 diabetes rat model via pancreatic alpha-amylase inhibition by highly condensed procyanidins. Biosci. Biotechnol. Biochem. 2017, 81, 1699-1705. [CrossRef] [PubMed]

36. Jiao, L.; Zhang, X.; Huang, L.; Gong, H.; Cheng, B.; Sun, Y.; Li, Y.; Liu, Q.; Zheng, L.; Huang, K. Proanthocyanidins are the major anti-diabetic components of cinnamon water extract. Food Chem. Toxicol. 2013, 56, 398-405. [CrossRef] [PubMed]

37. Arias, N.; Macarulla, M.; Aguirre, L.; Martinez-Castano, M.; Portillo, M. Quercetin can reduce insulin resistance without decreasing adipose tissue and skeletal muscle fat accumulation. Genes Nutr. 2014, 9, 361. [CrossRef] [PubMed]

38. Ogura, K.; Ogura, M.; Shoji, T.; Sato, Y.; Tahara, Y.; Yamano, G.; Sato, H.; Sugizaki, K.; Fujita, N.; Tatsuoka, H. Oral administration of apple procyanidins ameliorates insulin resistance via suppression of pro-inflammatory cytokine expression in liver of diabetic ob/ob mice. J. Agric. Food Chem. 2016, 64, 8857-8865. [CrossRef] [PubMed]

39. Cheng, H.; Xu, N.; Zhao, W.; Su, J.; Liang, M.; Xie, Z.; Wu, X.; Li, Q. (-)-Epicatechin regulates blood lipids and attenuates hepatic steatosis in rats fed high-fat diet. Mol. Nutr. Food Res. 2017, 61, 1700303. [CrossRef] [PubMed]

40. Luo, Y.; Burrington, C.M.; Graff, E.C.; Zhang, J.; Judd, R.L.; Suksaranjit, P.; Kaewpoowat, Q.; Davenport, S.K.; O'Neill, A.M.; Greene, M.W. Metabolic phenotype and adipose and liver features in a high-fat Western diet-induced mouse model of obesity-linked NAFLD. Am. J. Physiol. Endocrinol. Metab. 2015, 310, E418-E439. [CrossRef] [PubMed]

41. Tilg, H.; Moschen, A.R. Insulin resistance, inflammation, and non-alcoholic fatty liver disease. Trends Endocrinol. Metab. 2008, 19, 371-379. [CrossRef] [PubMed]

42. Koonen, D.P.; Jacobs, R.L.; Febbraio, M.; Young, M.E.; Soltys, C.-L.M.; Ong, H.; Vance, D.E.; Dyck, J.R. Increased hepatic CD36 expression contributes to dyslipidemia associated with diet-induced obesity. Diabetes 2007, 56, 2863-2871. [CrossRef] [PubMed]

43. Cao, Y.-W.; Jiang, Y.; Zhang, D.-Y.; Zhang, X.-J.; Hu, Y.-J.; Li, P.; Su, H.; Wan, J.-B. The hepatoprotective effect of aqueous extracts of Penthorum chinense Pursh against acute alcohol-induced liver injury is associated with ameliorating hepatic steatosis and reducing oxidative stress. Food Funct. 2015, 6, 1510-1517. [CrossRef] [PubMed]

44. Im, A.-R.; Kim, Y.H.; Lee, H.W.; Song, K.H. Water extract of Dolichos lablab attenuates hepatic lipid accumulation in a cellular nonalcoholic fatty liver disease model. J. Med. Food 2016, 19, 495-503. [CrossRef] [PubMed]

45. Pisonero-Vaquero, S.; Martínez-Ferreras, Á.; García-Mediavilla, M.V.; Martínez-Flórez, S.; Fernández, A.; Benet, M.; Olcoz, J.L.; Jover, R.; González-Gallego, J.; Sánchez-Campos, S. Quercetin ameliorates dysregulation of lipid metabolism genes via the PI3K/AKT pathway in a diet-induced mouse model of nonalcoholic fatty liver disease. Mol. Nutr. Food Res. 2015, 59, 879-893. [CrossRef] [PubMed]

46. Wang, Z.; Kim, J.H.; Jang, Y.S.; Kim, C.H.; Lee, J.-Y.; Lim, S.S. Anti-obesity effect of Solidago virgaurea var. g igantea extract through regulation of adipogenesis and lipogenesis pathways in high-fat diet-induced obese mice (C57BL/6N). Food Nutr. Res. 2017, 61, 1273479. [CrossRef] [PubMed]

47. Jeong, E.J.; Jegal, J.; Ahn, J.; Kim, J.; Yang, M.H. Anti-obesity effect of Dioscorea oppositifolia extract in high-fat diet-induced obese mice and its chemical characterization. Boil. Pharm. Bull. 2016, 39, 409-414. [CrossRef] [PubMed]

48. Ji, W.; Zhao, M.; Wang, M.; Yan, W.; Liu, Y.; Ren, S.; Lu, J.; Wang, B.; Chen, L. Effects of canagliflozin on weight loss in high-fat diet-induced obese mice. PLoS ONE 2017, 12, e0179960. [CrossRef] [PubMed]

49. Wu, T.; Yu, Z.; Tang, Q.; Song, H.; Gao, Z.; Chen, W.; Zheng, X. Honeysuckle anthocyanin supplementation prevents diet-induced obesity in C57BL/ 6 mice. Food Funct. 2013, 4, 1654-1661. [CrossRef] [PubMed]

50. Lee, A.-Y.; Kang, M.-J.; Choe, E.; Kim, J.-I. Hypoglycemic and antioxidant effects of Daraesoon (Actinidia arguta shoot) in animal models of diabetes mellitus. Nutr. Res. Pr. 2015, 9, 262-267. [CrossRef] [PubMed]

51. Shen, K.-P.; Su, C.-H.; Lu, T.-M.; Lai, M.-N.; Ng, L.-T. Effects of Grifola frondosa non-polar bioactive components on high-fat diet fed and streptozotocin-induced hyperglycemic mice. Pharm. Boil. 2015, 53, 705-709. [CrossRef] [PubMed] 
52. Terra, X.; Pallarés, V.; Ardèvol, A.; Bladé, C.; Fernández-Larrea, J.; Pujadas, G.; Salvadó, J.; Arola, L.; Blay, M. Modulatory effect of grape-seed procyanidins on local and systemic inflammation in diet-induced obesity rats. J. Nutr. Biochem. 2011, 22, 380-387. [CrossRef] [PubMed]

53. Vazquez Prieto, M.A.; Bettaieb, A.; Rodriguez Lanzi, C.; Soto, V.C.; Perdicaro, D.J.; Galmarini, C.R.; Haj, F.G.; Miatello, R.M.; Oteiza, P.I. Catechin and quercetin attenuate adipose inflammation in fructose-fed rats and 3T3-L1 adipocytes. Mol. Nutr. Food Res. 2015, 59, 622-633. [CrossRef] [PubMed]

54. Draper, H.; Hadley, M. Malondialdehyde determination as index of lipid peroxidation. Methods Ezymol. 1990, 86, 421-431.

55. Hamed, E.A.; Zakary, M.M.; Ahmed, N.S.; Gamal, R.M. Circulating leptin and insulin in obese patients with and without type 2 diabetes mellitus: Relation to ghrelin and oxidative stress. Diabetes Res. Clin. Pract. 2011, 94, 434-441. [CrossRef] [PubMed]

56. Karczewska-Kupczewska, M.; Strączkowski, M.; Adamska, A.; Nikołajuk, A.; Otziomek, E.; Górska, M.; Kowalska, I. Increased suppression of serum ghrelin concentration by hyperinsulinemia in women with anorexia nervosa. Eur. J. Endocrinol. 2010, 162, 235-239. [CrossRef] [PubMed]

57. Yamashita, Y.; Okabe, M.; Natsume, M.; Ashida, H. Cinnamtannin A2, a tetrameric procyanidin, increases GLP-1 and insulin secretion in mice. Biosci. Biotechnol. Biochem. 2013, 77, 888-891. [CrossRef] [PubMed]

58. DeOliveira, C.C.; Acedo, S.C.; Gotardo, É.M.F.; de Oliveira Carvalho, P.; Rocha, T.; Pedrazzoli, J.; Gambero, A. Effects of methotrexate on inflammatory alterations induced by obesity: An in vivo and in vitro study. Mol. Cell. Endocrinol. 2012, 361, 92-98. [CrossRef] [PubMed]

59. Folch, J.; Lees, M.; Sloane-Stanley, G. A simple method for the isolation and purification of total lipids from animal tissues. J. Biol. Chem. 1957, 226, 497-509. [PubMed]

60. Nakamitsu, P.Z.; Compri, C.M.; de Fraia, P.L.; Gotardo, E.M.; de Oliveira, C.C.; Ribeiro, M.L.; Pedrazzoli, J., Jr.; Gambero, A. Thalidomide controls adipose tissue inflammation associated with high-fat diet-induced obesity in mice. Endocr. Metab. Immune Disord. Drug Targets 2015, 15, 151-158. [CrossRef] [PubMed]

Sample Availability: Samples of the compounds are available from the authors.

(C) 2018 by the authors. Licensee MDPI, Basel, Switzerland. This article is an open access article distributed under the terms and conditions of the Creative Commons Attribution (CC BY) license (http:/ / creativecommons.org/licenses/by/4.0/). 